\title{
Geologia, controle estrutural e mineralogia do escarnito mineralizado em ouro e tungstênio da Mina Bonfim-II, Província Borborema, Rio Grande do Norte, Brasil
} Geology, structural control and mineralogy of gold and tungsten mineralized skarn at Bonfim Mine, Borborema Province, Rio Grande do Norte, Brazil.

Eduardo Henrique Rodrigues Pereira' ${ }^{1}$ (D), Nilson Francisquini Botelho' ${ }^{10}$, Claudinei Gouveia de Oliveira ${ }^{1}$ (D) Eduardo Valentin dos Santos ${ }^{1}$ (D)

${ }^{1}$ Universidade de Brasília - UnB, Instituto de Geociências, Campus Darcy Ribeiro, Asa Norte, CEP 70910-900, Brasília, DF, BR. (eduhenrique975@gmail.com; nilsonfb@unb.br; gouveia@unb.br; eduardovalentindossantos@gmail.com)

Recebido em 18 de novembro de 2018; aceito em 11 de setembro de 2019

\begin{abstract}
Resumo
A Mina Bonfim é caracterizada por camadas de mármores em contato com flogopita xistos subjacentes, ao longo do qual se desenvolveu o escarnito rico em tungstênio e ouro, disposto seguindo a orientação $\mathrm{N} 10^{\circ} \mathrm{E} / 30^{\circ} \mathrm{SE}$, cisalhado e estruturado sob a forma de boudins, em baixo ângulo de caimento $\left(12^{\circ}\right)$ ao longo da direção $\mathrm{N} 10^{\circ} \mathrm{E}$. A scheelita encontra-se nos boudins, associando-se à molibdenita, ambas sendo formadas sob condições sin-tectônicas dúcteis, consistindo na primeira fase de mineralização. O ouro encontra-se em fraturas de cisalhamento tardias, com orientação $\mathrm{N} 70^{\circ} \mathrm{W} / 75^{\circ} \mathrm{SW}$, que seccionam e deslocam o escarnito scheelitífero. As fraturas são preenchidas por prehnita (ganga), ouro e minerais de bismuto, indicando que a precipitação do ouro ocorreu na fácies prehnita-pumpelliyta, sob regime dúctil-rúptil, que corresponde à segunda fase de mineralização. O ouro é rico em prata com até $16,09 \% \mathrm{Ag}$, e suas formas de ocorrência são: livre na ganga, em fraturas ou em contato com bismuto, bismutinita e joseíta, constituindo a paragênese aurífera. Grãos de ouro exibem bismuto na composição, podendo chegar a $0,44 \% \mathrm{Bi}$. O minério está hospedado em escarnito reduzido, gerado em estágios progressivo e retrogressivo, produto do metassomatismo em mármores alterados por fluidos carreados ao longo de estruturas.
\end{abstract}

Palavras-chave: Escarnito; Bonfim; Scheelita; Ouro; Fraturas; Prehnita.

\begin{abstract}
The Bonfim Mine is characterized by marbles layers in contact with underlying phlogopite schists, along which gold- and tungsten-rich skarns were developed, in $\mathrm{N} 10^{\circ} \mathrm{E} / 30^{\circ} \mathrm{SE}$ direction, sheared and structured as boudins plunging $12^{\circ}$ to $\mathrm{N} 10^{\circ} \mathrm{E}$. Scheelite is found in the boudins, associated to molybdenite, both being formed under ductile syntectonic conditions, consisting of the first phase of mineralization. Gold is found in late shear fractures, oriented $\mathrm{N} 70^{\circ} \mathrm{W} / 75^{\circ} \mathrm{SW}$, that cut and displace the scheelitiferous skarn. The fractures are filled by prehnite (gangue), gold and bismuth minerals, indicating that gold precipitation occurred in the prehnite-pumpelliyte facies under ductile-brittle regime, which corresponds to the $2^{\text {nd }}$ phase of mineralization. The gold is rich in silver with up to $16.09 \% \mathrm{Ag}$ and its occurrences are: free in gangue, in fractures and in contact with bismuth, bismuthinite and joséite, constituting auriferous paragenesis. Gold grains show bismuth in its microprobe analyses composition, reaching up to $0.44 \% \mathrm{Bi}$. The ore is hosted in a reduced skarn, generated in progressive and retrogressive stages, the product of metasomatism in marbles altered by fluids carried along the structures.
\end{abstract}

Keywords: Skarn; Bonfim; Scheelite; Gold; Fractures; Prehnite. 


\section{INTRODUÇÃO}

A scheelita de Bonfim foi descoberta em 1969 por Eurico Pereira, filho de Raul Pereira da Silva (Raul Capitão), dono da Fazenda Bonfim, a sudeste da cidade de Lajes, Rio Grande do Norte, Brasil, extraída inicialmente sob a forma de garimpo. Entre 1970 e 1971, a Companhia de Pesquisa e Recursos Minerais (CPRM, 1971) executou duas campanhas de sondagem rotativa diamantada nas áreas de Bonfim-I e Bonfim-II, totalizando 2.887,92 m distribuídos em 24 furos, o que permitiu a compreensão da geologia e do comportamento dos corpos de minério, possibilitando a lavra subterrânea até o início dos anos 1980, quando houve a queda no preço internacional do tungstênio.

A existência de ouro em Bonfim ficou conhecida apenas a partir de 1992, quando Antônio Cassiano Lopes da Silva, prospector do Seridó, identificou minúsculas pintas de ouro em bateia no riacho das nuvens (relatos verbais de Eurico Pereira e Antônio Cassiano).

A notícia de ouro na década de 1990 atraiu mineradoras de grande porte, tendo em vista o potencial para a existência de um depósito de classe mundial, entre as quais se destacam a Docegeo, a Rio Tinto Desenvolvimento Mineral (RTDM-RTZ) e a São Bento Mineração Ltda., que fizeram trabalhos prospectivos para ouro. Contudo, os resultados não indicaram grande potencial econômico.

Bonfim encontra-se disposto de modo concordante com as extensas zonas de cisalhamento de direção NNE-SSW que caracterizam o arcabouço estrutural da parte nordeste da Província Borborema (Figura 1), que corresponde ao trend da Formação Seridó, composta de biotita xistos metamorfisados e deformados durante o último evento orogênico, o Brasiliano, que afetou a região há $600 \mathrm{Ma}$ (Van Schmus et al., 2003).

Intercalações de mármores bandados de composição calcítica, dolomítica e silicosa, dispostos segundo a direção $\mathrm{N} 10^{\circ} \mathrm{E}$, com baixo ângulo de mergulho $\left(20 \mathrm{a} 30^{\circ}\right)$ para SE, compõem o pacote carbonático conhecido como Horizonte Bonfim (Docegeo, 1996), em cuja base se desenvolveu uma camada de escarnito em contato concordante e gradacional com flogopita xistos subjacentes, que corresponde ao corpo principal de minério da Mina Bonfim-II, o Corpo B.

A unidade de flogopita xistos é formada por xistos, por vezes com porfiroblastos de granada, exibindo sulfetação fina disseminada ou em bolsões milimétricos, com predomínio de pirrotita, tendo calcopirita subordinada. Isso sugere um ambiente de formação em condições redutoras (Souza Neto et al., 2008).

Em Bonfim-II, existem ainda os corpos de minério A e C, o primeiro no contato de topo do pacote de mármores com os xistos sobrepostos (Xisto Seridó), e o Corpo C posicionado $2 \mathrm{~m}$ abaixo do Corpo B, dentro da unidade de flogopita xistos, porém ambos com menor importância econômica.
O Corpo A não foi lavrado porque é muito estreito $(10 \mathrm{~cm})$ e o Corpo C foi lavrado em parte, contudo o baixo teor de ouro inviabilizou a sua extração.

Na região de Bonfim, existem duas minas subterrâneas: Bonfim-I, a mais antiga, tendo sido lavrada desde 1969, e que corresponde à mina onde se concentram todos os trabalhos existentes sobre Bonfim; e Bonfim-II, a mais recente, situada $1 \mathrm{~km}$ a nordeste, no trend estrutural NNE-SSW. Além disso, existe ainda um terceiro depósito, Bonfim-III, situado $500 \mathrm{~m}$ a nordeste de Bonfim-II, conhecido apenas por sondagem a $400 \mathrm{~m}$ de profundidade. Desse modo, os depósitos de Bonfim, dispostos ao longo do trend estrutural NNE, foram definidos neste trabalho como o Sistema Estrutural Bonfim (SEB), correspondendo aos três depósitos de minério escarnítico dispostos sob a forma de boudins com plunge de baixo ângulo $\left(12^{\circ}\right)$ para NNE. Portanto, o SEB mostra que ainda existe potencial exploratório para a descoberta de novos depósitos de minério de ouro e tungstênio na região de Bonfim.

\section{GEOLOGIA REGIONAL}

A Província Borborema corresponde a uma sequência supracrustal proterozoica composta de rochas sedimentares e vulcânicas metamorfisadas que repousam sobre embasamento gnáissico migmatítico, sendo que todas as unidades litológicas estão cortadas por intrusões graníticas brasilianas (Almeida et al., 1977). O conjunto das unidades litoestratigráficas caracterizam o cinturão orogênico compartimentado tectonicamente em domínios (Almeida et al., 1981), que no estado do Rio Grande do Norte são subdivididos em domínio São José do Campestre, na parte leste, domínio Rio Piranhas-Seridó, no centro do estado, e domínio Jaguaribeano, no extremo oeste (Angelim et al., 2006).

A Mina Bonfim está situada no extremo nordeste da Província Borborema, no domínio Rio Piranhas-Seridó, em rochas sedimentares metamorfisadas em fácies anfibolito que compõem o Grupo Seridó (Figura 1), este repousando sobre ortognaisses do Complexo Caicó (Jardim de Sá, 1984), que compõem o embasamento gnáissico. Parte dos ortognaisses foram classificados em granitos G1 e G2 por Jardim de Sá (1994), e que apresentam idades riacianas (Hollanda et al., 2011; Medeiros et al., 2012). Foram diferenciados do Complexo Caicó, gnaisses e migmatitos de composição granodiorítica a tonalítica, de idade Sideriana (2.46 Ga), que compreendem o Complexo Arábia (Costa e Dantas, 2018). O magmatismo granítico brasiliano está presente sob a forma de plútons, stocks e batólitos com composições variadas, que ocorrem intrusivos nas unidades anteriores.

A sequência metavulcanossedimentar presente a oeste de Bonfim e a leste da Serra do Feiticeiro, composta de termos básicos a ácidos com assinatura geoquímica de rochas 
vulcânicas, corresponde a uma unidade basal arqueana do Complexo Caicó, definida informalmente como Sequência Amarante por Carvalho (1990).

Integrando ainda o embasamento da região, encontra-se o Maciço São José do Campestre (Figura 2), constituído de gnaisses e migmatitos de idade arqueana, datados no intervalo 3,4-2,7 Ga, por Dantas et al. (2004), que corresponde ao núcleo arqueano mais antigo conhecido na Província Borborema.

O Grupo Seridó é composto de três formações principais, considerando o empilhamento proposto por Jardim de

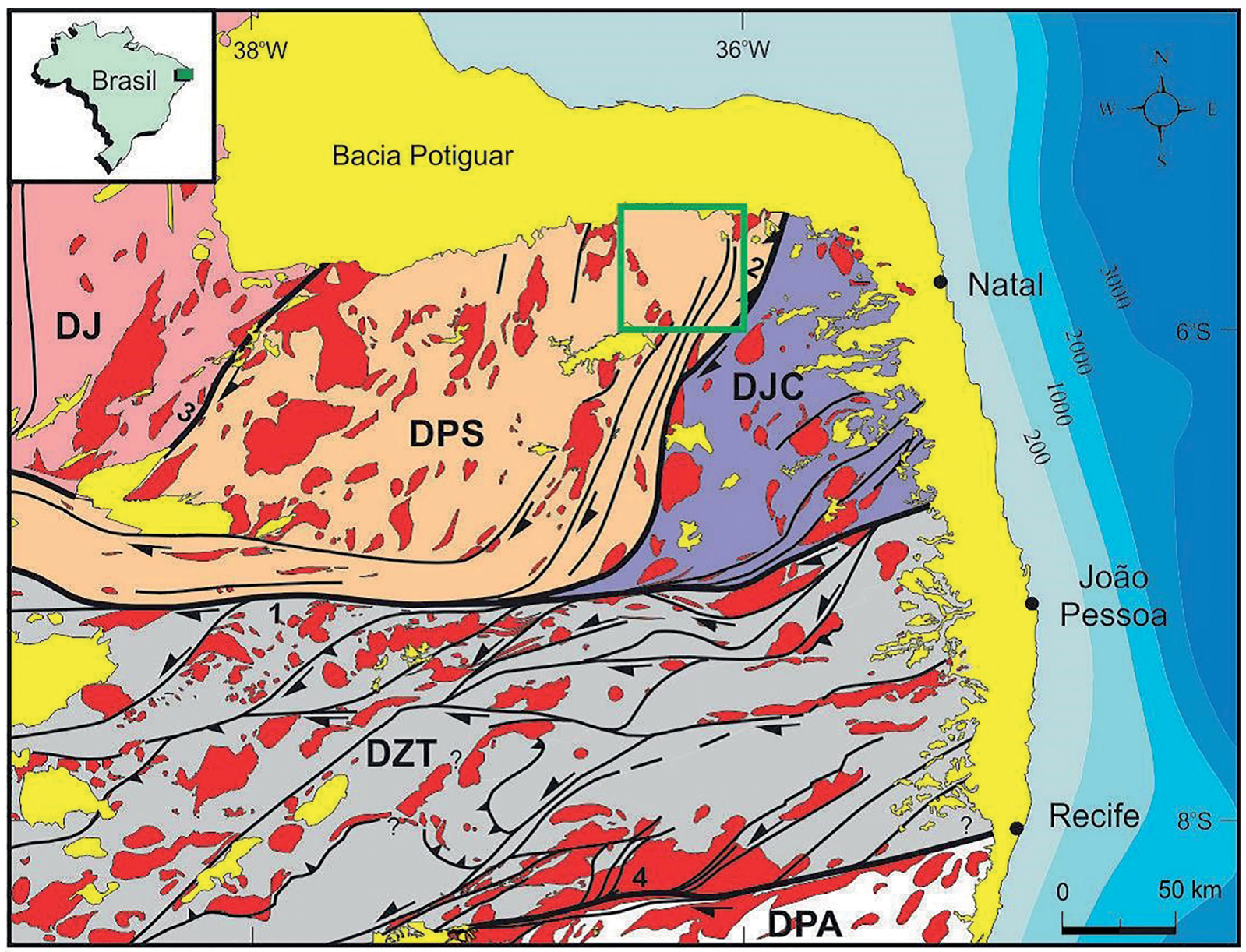

Fonte: Medeiros (2011)

\section{$\square$ Coberturas Fanerozoicas}

\section{$\square$ Granitóides Brasilianos}

\section{DJ - Domínio Jaguaribeano}

DPS - Domínio Rio Piranhas-Seridó

DJC - Domínio São José do Campestre

\section{DZT - Domínio da Zona Transversal}

\section{DPA - Domínio Pernambuco-Alagoas}

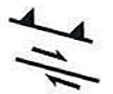

Zonas de cisalhamento

1) Patos

3) Portalegre

2) Picuí-João Câmara

4) Pernambuco

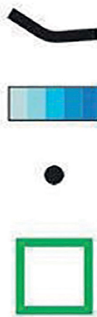

\section{Limites de domínios}

Intervalos batimétricos (metros)

\section{Cidade}

\section{Folha Lajes}

Figura 1. Quadro geológico regional da porção setentrional da Província Borborema, destacando os vários domínios. A região deste trabalho situa-se no Domínio Rio Piranhas-Seridó (Complexo Caicó), incluindo o Grupo Seridó, representado por rochas metassedimentares, além dos granitos granitoides brasilianos individualizados na Suíte Ígnea Brasiliana. Destaca-se a área da folha geológica Lajes, na qual está inserido o depósito Bonfim. 
Sá e Salim (1980) e Jardim de Sá (1984). Tem-se na base a Formação Jucurutu (mármores e rochas calcossilicáticas), sobreposta pela Formação Equador (quartzitos), tendo no topo pelitos da Formação Seridó. Os metapelitos são constituídos de granada-biotita xistos, por vezes com cianita e/ou sillimanita, e/ou andaluzita e/ou cordierita, que correspondem a metassedimentos argiloaluminosos brasilianos.

Admite-se uma evolução polifásica para as rochas metamórficas, metavulcânicas e/ou metassedimentares intensamente deformadas, cisalhadas e dobradas, e os terrenos mais antigos teriam sofrido deformação e metamorfismo no paleoproterozoico. As estruturas primárias principais foram reativadas e retrabalhadas juntamente com faixas móveis mais recentes, amalgamadas durante a evolução do Ciclo Brasiliano (Jardim de Sá et al., 1987), que corresponde ao último evento tectonometamórfico registrado na região Nordeste do Brasil, ocorrido há cerca de $600 \mathrm{Ma}$.

O Complexo Caicó e o Grupo Seridó, segundo Jardim de Sá $(1984,1994)$ e Jardim de Sá et al. (1987), sofreram três fases deformacionais principais, D1, D2 e D3, relacionadas aos eventos metamórficos concomitantes, M1, M2 e M3, sendo que as duas primeiras fases afetaram apenas o embasamento, em condições de metamorfismo fácies anfibolito superior, e a última fase afetou todo o conjunto. A fase D1 pode ser interpretada como responsável pela formação de um bandamento composicional (ou foliação) S1//So, ou $\mathrm{Sn} / / \mathrm{So}$, marcado pela alternância de bandas escuras ricas em minerais máficos (biotita e hornblenda) e bandas claras quartzo-feldspáticas (Souza et al., 2017).

O evento deformacional (D2) está associado a um sistema contracional, com empurrões gerando dobramentos recumbentes, com transposição nos flancos, o que estaria relacionado ao evento metamórfico M2 (Souza et al., 2017) de alto grau metamórfico (fácies anfibolito). Desse modo, o bandamento gerado na fase D1 foi dobrado pelo evento D2, gerando uma foliação plano axial (S2), paralela ao bandamento metamórfico ou foliação metamórfica (S1).

A terceira fase de deformação (D3) corresponde à fase de encurtamento crustal com a verticalização dos estratos e a formação de dobras sinformes e antiformes, abertas a

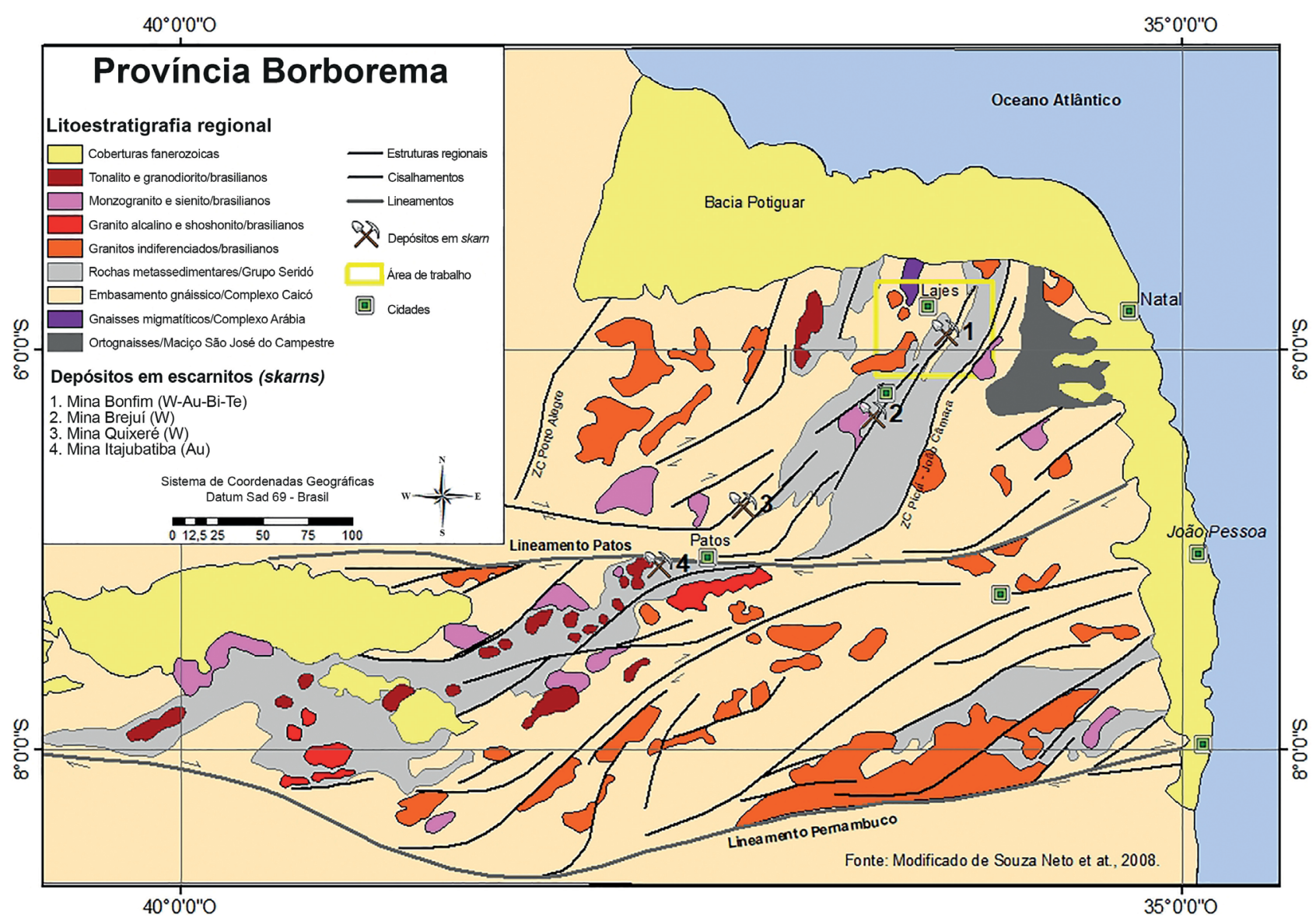

Figura 2. Mapa geológico regional da Província Borborema, destacando as distintas unidades litoestratigráficas presentes, desde o embasamento arqueano a paleoproterozoico aos granitos brasilianos. Encontra-se ainda a localização dos principais depósitos de scheelita e ouro, com ênfase ao depósito Bonfim na área de trabalho. 
isoclinais, com a presença de uma foliação (S3) com orientação regional NNE-SSW, associada à cinemática transcorrente brasiliana, caracterizada por zonas de cisalhamento que exibem trend estrutural NE-SW. O evento metamórfico brasiliano M3 afetou tanto as rochas do embasamento quanto as litologias do Grupo Seridó, em condições de fácies xisto verde, superimposto aos eventos metamórficos anteriores. Uma quarta fase de deformação (D4) foi descrita por Hackspacher e Sá (1984), que corresponde a uma fase com fraca penetratividade e disposta segundo o trend NW-SE.

Os granitos relacionados à orogênese Brasiliana ocorrem estruturados por zonas de cisalhamento transcorrentes, correspondendo a corpos sintectônicos, ou pós-tectônicos, intrudidos durante os períodos Ediacarano e Cambriano (Archanjo et al., 2013). Considerando características petrográficas, geoquímicas e geocronológicas, esse plutonismo foi dividido em seis suítes magmáticas: shoshonítica, calcioalcalina de alto $\mathrm{K}$ porfirítica, calcioalcalina de alto $\mathrm{K}$ equigranular, calcioalcalina, alcalina e alcalina charnockítica (Nascimento et al., 2015).

Representantes dessa granitogênese brasiliana foram datados, como a suíte intrusiva São João do Sabugi, com idade de $579 \pm 7 \mathrm{Ma}$ (Leterrier et al., 1994), e o plúton de Acarí com idade U-Pb TIMs de $555 \pm 5 \mathrm{Ma}$ (Legrand et al., 1991), e U-Pb SHRIMP de $577 \pm 4,5 \mathrm{Ma}$ (granito porfirítico) e $572 \pm 4,6 \mathrm{Ma}$ (leucogranito), ambos no maciço granítico de Acarí (Archanjo et al., 2013).

As idades das mineralizações de scheelita das minas Brejuí, Bodó e Bonfim foram obtidas por datações Re-Os em molibdenita, tendo sido determinado, para Brejuí, $554 \pm 2 \mathrm{Ma}$; para Bodó, $510 \pm 2 \mathrm{Ma}$; e para Bonfim, $524 \pm 2 \mathrm{Ma}$, indicando três episódios mineralizantes no Grupo Seridó, associados a pulsos recorrentes de magmatismo ácido tardi-brasiliano (Hollanda et al., 2017).

O depósito de tungstênio Bonfim está hospedado no "Horizonte Bonfim", que é representado por um pacote de mármores junto com rochas calciossilicáticas, dispostos acima de biotita gnaisses (base do Grupo Seridó), tendo no topo biotita xistos granadíferos. A sequência corresponde à macroestrutura sinformal de Bonfim, que possui eixo com caimento $10^{\circ} / \mathrm{NNE}$ (Salim, 1979). Essa estruturação estaria relacionada à terceira fase de deformação $\left(\mathrm{D}_{3}\right)$, caracterizada por sucessivas dobras sinformes e antiformes com plano axial subvertical, relacionado a uma foliação plano axial $\mathrm{S}_{3}$, com atitude $\mathrm{N} 15^{\circ} \mathrm{E} / 80^{\circ} \mathrm{SE}$, ortogonal à foliação $\mathrm{S}_{2}$ da segunda fase de deformação $\left(\mathrm{D}_{2}\right)$, constituída de dobras recumbentes, conforme observado por Salim (1979).

$\mathrm{O}$ último magmatismo relacionado à orogênese brasiliana pode ser atribuído às intrusões pegmatíticas compostas de K-feldspato, quartzo, muscovita e biotita, que cortam rochas do embasamento gnáissico (Complexo Caicó) e faixas metassedimentares da Formação Seridó. Os pegmatitos são discordantes de todas as litologias, estando dispostos segundo a direção NW-SE, exibindo xenólitos de suas encaixantes, notadamente dos xistos da Formação Seridó. Datações U-Pb obtidas em columbita-tantalita por Baumgartner et al. (2006), revelam idades de $514 \pm 1,1 \mathrm{e}$ $509 \pm 2,3 \mathrm{Ma}$, as quais corresponderiam à fase tardia da orogenia brasiliana.

No meso-cenozoico, durante a instalação da bacia potiguar, ocorreu o último episódio magmático no Rio Grande do Norte, responsável pela abertura de fraturas extensionais de direção WNW à E-W, nas quais se encaixam diques básicos de composição basáltica, de idade cretácica, consolidando o cenário tectônico e geológico da região do Seridó.

\section{DEPÓSITOS W-AU DA REGIÃO DO SERIDÓ}

A evolução tectonometamórfica do Grupo Seridó está relacionada à orogenia Brasiliana (ca. $600 \mathrm{Ma}$ ), com os depósitos de tungstênio e ouro relacionados às intrusões graníticas em sequências metassedimentares. Os horizontes mineralizados ocorrem em mármores dolomíticos afetados por fluidos graníticos que levaram à geração de escarnitos por metassomatismo, os quais estão mineralizados em tungstênio (scheelita) e ouro. A maior parte dos depósitos de scheelita em escarnitos estão próximos a corpos graníticos (Figura 2), contudo alguns possuem caráter distal, com fluidos conduzidos por meio de zonas de cisalhamento.

Na região do Seridó, as condições de pico do metamorfismo do evento brasiliano foram estabelecidas em $550-600^{\circ} \mathrm{C}$ e 3-4 kbars, baseado em condições geotermobarométricas (Gama Jr. e Albuquerque, 1985; Lima, 1986).

Os principais depósitos de tungstênio do Seridó são Brejuí, Bodó, Bonito, Quixeré, Quixaba, Malhada Limpa, Bonfim e Itajubatiba, além de centenas de ocorrências de pequeno porte (Lima et al., 1980). Os depósitos compreendem escarnitos scheelitíferos oxidados, ricos em pirita, exceto Bonfim e Itajubatiba (Figura 2), que são mineralizados em ouro e possuem pirrotita como principal sulfeto, sendo considerados como escarnitos reduzidos (Souza Neto et al., 2008).

Bonfim e Itajubatiba apresentam características similares, tais como as rochas encaixantes, a morfologia dos escarnitos, a mineralogia dos estágios progressivo e retrogressivo e os minerais de minério.

A mineralização em Bonfim foi definida como escarnito desenvolvido em estágios progressivo e retrogressivo por Souza Neto et al. (2008), cujos minerais presentes no estágio progressivo seriam almandina, diopsídio, anortita e actinolita-magnésio-hornblenda. O estágio retrogressivo, por sua vez, teria sido marcado por álcali-feldspato, zoizita-clinozoizita-sericita substituindo anortita do estágio progressivo, além de calcita e clorita.

O ouro em Bonfim está associado ao estágio tardio da mineralização, de modo que se encontra disseminado, 
juntamente com minerais pretos de granulação fina, que ocorrem preenchendo estreitas falhas dúcteis-rúpteis conjugadas, além de fraturas extensionais (Souza Neto et al., 2008). Em Itajubatiba, o ouro é controlado por cisalhamentos e fraturas, caracterizado pela associação com ferro e cobre (Souza Neto et al., 2008).

Elevados teores de flúor (até 9,490 ppm) foram encontrados em titanita e zoizita-clinozoizita, indicando a presença de fluidos metassomáticos ricos em flúor durante a formação do escarnito em Bonfim (Souza Neto et al., 1998).

\section{METODOLOGIA}

O presente artigo é o produto do trabalho de acompanhamento da abertura de galerias de desenvolvimento e de lavra da mina subterrânea Bonfim-II, por meio do mapeamento geológico-estrutural sistemático, desde a abertura da mina, no começo de 2013, até o fim de 2016, o que permitiu a definição da geologia e da estrutura do Corpo B de minério.

Foram coletadas 40 amostras do escarnito mineralizado in situ, nas galerias e nas câmaras da mina subterrânea, para estudos petrográficos sob luz transmitida e refletida, e também para análises por microssonda eletrônica no laboratório de microssonda eletrônica do Instituto de Geociências da Universidade de Brasília (IG/UnB), para caracterização do minério de ouro e sua paragênese sulfetada. As lâminas polidas e seções polidas para a minerografia foram feitas seccionando as fraturas preenchidas por minerais escuros de bismuto, as quais hospedam a mineralização aurífera.

Os objetivos deste trabalho, considerando os fatos obtidos por meio das observações feitas em subsolo aliadas à petrografia, são definir a geologia e o controle estrutural do corpo de minério, principalmente da mineralização aurífera em Bonfim-II, contribuindo para a identificação de novos minerais na assembleia mineralógica do escarnito, e caracterizar o minério de ouro e sua paragênese sulfetada.

As análises químicas dos minerais foram feitas na microssonda eletrônica (Electron Probe Micro Analyser EPMA) Jeol Modelo Superprobe JXA-8230, com microscópio eletrônico de varredura (MEV), por meio do método de dispersão por energia (EDS) e por comprimento de ondas (WDS), cujas condições analíticas utilizadas foram $20 \mathrm{KV}$ de voltagem de aceleração e $20 \mathrm{nA}$ de feixe de corrente, com tempo de contagem para todos elementos no pico e background de 5 e $10 \mathrm{~s}$, tendo sido usada para as análises a microssonda eletrônica do IG/UnB.

\section{GEOLOGIA DA MINA}

Os xistos da Formação Seridó recobrem toda a região de contato entre ortognaisses e rochas calcossilicáticas (escarnitos), afetadas por intrusões pegmatíticas (Figura 3), de modo que o corpo de minério da Mina Bonfim-II se encontra $90 \mathrm{~m}$ abaixo da superfície.

A rampa de acesso à mina foi escavada em biotita xistos (Formação Seridó) e desenvolvida ao longo de rochas calcossilicáticas e mármores com estrutura bandada disposta segundo a orientação $\mathrm{N} 10^{\circ} \mathrm{E} / 30^{\circ} \mathrm{SE}$, os quais corresponderiam à Formação Jucurutu. A unidade de mármores é constituída de tremolita-flogopita mármores de composição silicosa (cor castanho-clara), com alternâncias de mármores calcíticos de cor salmão e mármores cristalinos dolomíticos de cor branca, cuja espessura chega a $18 \mathrm{~m}$.

O corpo de minério é um escarnito que ocorre sob a forma de camada máfica (escura), bandada, competente e estreita $(<1 \mathrm{~m})$, disposta segundo a direção $\mathrm{N} 10^{\circ} \mathrm{E} / 30^{\circ} \mathrm{SE}$, abaixo do pacote de tremolita-flogopita mármores por contato brusco e concordante, e acima da unidade subjacente de flogopita xistos, com contato concordante e gradacional.

É possível observar no escarnito uma zonação vertical na qual o contato de topo com tremolita-flogopita mármores marcaria a zona superior, que por vezes pode estar preenchido por molibdenita maciça. Logo abaixo se define a zona central do escarnito, rica em diopsídio e actinolita (zona do diopsídio), de cor verde-escura com espessura de 0,50 a $1 \mathrm{~m}$ (Figura 4), mineralizada em scheeelita e molibdenita, podendo ser associada ao estágio progressivo de formação do escarnito. Por contato brusco, abaixo da zona central encontra-se a zona inferior, com níveis de zoizita-clinozoizita (rosada) ao longo da foliação reliquiar (zona da clinozoizita), indicativa do estágio retrogressivo do escarnito, proveniente da alteração metassomática de flogopita xistos subjacentes. A zona inferior é marcada por grande quantidade de falhas e fraturas de cisalhamento subverticais de direção NW-SE (Figura 4), preenchidas por minerais metálicos escuros de bismuto, intimamente associados à mineralização aurífera.

O mapeamento geológico do corpo de minério na região de contato do pacote de mármores com flogopita xistos, permitiu individualizar dois tipos de escarnito, considerando o protólito: o escarnito máfico formado a partir da alteração metassomática da camada de mármore, que corresponde à zona central do escarnito; e o escarnito félsico de cor verde-clara, que exibe fraturas subverticais com minerais de bismuto de cor preta, mineralizadas em ouro, que fazem parte da zona inferior do escarnito, formada a partir da alteração de flogopita xistos que constituem a unidade basal da sequência litológica mapeada na mina.

O escarnito encontra-se boudinado com plunge de baixo ângulo de caimento $\left(12^{\circ}\right)$ ao longo da direção principal $\mathrm{N} 10^{\circ} \mathrm{E}$ (Figura 5), correspondendo ao eixo do boudin, que estruturalmente corresponde ao pescoço ou neck do boudin.

Observam-se feições de boudinagem associadas às variações na espessura do corpo de minério, conforme pode ser visto nas câmaras de lavra da mina, onde se observa boudins 


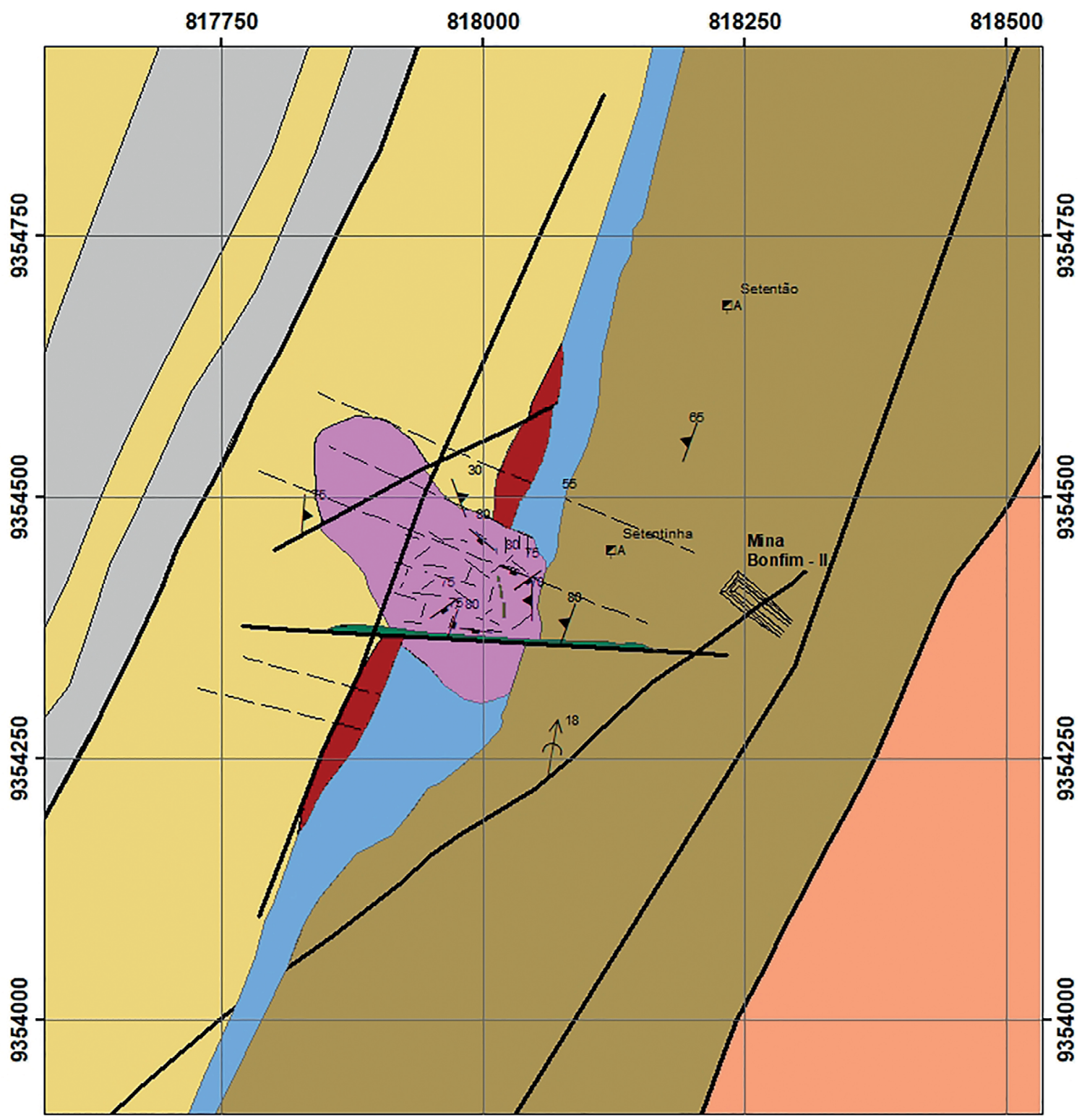

Unidades Litoestratigráficas Magmatismo Cretácico

Dique basalto

Intrusões Brasilianas

Pegmatitos

Grupo Seridó

Formação Seridó

Biotita Xisto (granada biotita xisto)

Formação Equador

$\square$ Quartzitos

Formação Jucurutu

Mármores

Escarnito mineralizado W-Mo/Au

0

Flogopita xisto, granada flogopita xisto Complexo Caicó

Ortognaisses bandados
号

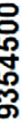

疋

옹

Mapa Geológico Bonfim - II Principais

Falhas

$\because$ Fraturas ( $\mathrm{Au}, \mathrm{Bi}, \mathrm{Te})$

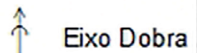

ـ Foliação

- Fraturas

- Sondagem

Mapeamento geológico s

de linhas leste-este

Geólogo: Eduardo H.R. Pereira

Base de dados: MNSB

Projeção: UTM

Datum: SAD69 Zona: 24S

\section{$1: 5.000$}

250

$\begin{array}{lll}0 & 62,5 & 125\end{array}$

Figura 3. Mapa geológico na região da Mina Bonfim-ll em escala 1:5.000. Destacam-se as falhas e as fraturas de direção NW que correspondem às estruturas tardias que controlam a mineralização aurífera. 
de escarnito ricos em scheelita com intervalos que sofrem estrangulamento abrupto, passando de $1 \mathrm{~m}$ de espessura para $0,10 \mathrm{~m}$. Nota-se também variações na largura do corpo de minério, o que é perceptível em escala de mapa, como pode ser visto no nível 215 da mina (Figura 6), evidenciando a forma boudinada do corpo de minério, individualizando os corpos de minério sul e norte. Esse nível está a $90 \mathrm{~m}$ de profundidade, considerando o emboque da rampa na cota $305 \mathrm{~m}$ acima do nível do mar.

O mapeamento geológico dos segmentos inferiores da mina também exibe o corpo de minério com a mesma estrutura, tendo boudins estéreis de mármore dolomítico internamente (Figura 7). No nível 188 da mina subterrânea foi mapeada uma camada de mármore dolomítico dentro do corpo de minério, em escala de detalhe 1:250 (Figura 7). Nota-se ainda a presença de boudins centimétricos de mármore dolomítico branco dentro da camada do escarnito máfico scheelitífero, os quais correspondem a porções reliquiares que não foram completamente transformadas em escarnitos (Figura 8C), sendo evidências de que o mármore dolomítico é o protólito do escarnito máfico.

A mineralização de tungstênio está presente sob a forma de cristais de scheelita, estirados ao longo do bandamento do escarnito máfico, exibindo o formato de boudins de scheelita (Figura 8E). Associado ao tungstênio, encontram-se concentrações significativas de molibdênio sob a forma de molibdenita, disseminada ou maciça, além de pirrotita disseminada e calcopirita subordinada.

A correlação genética e estrutural da scheelita no escarnito mostra que a mineralização de tungstênio possui caráter sin-tectônico, consistindo na primeira fase de mineralização, correspondente ao sistema W-Mo. Os boudins de scheelita podem ser vistos nitidamente sob luz ultravioleta, em razão da fluorescência da scheelita, que em Bonfim exibe cor azul neon típica (Figura 8F).

Abaixo do pacote de mármores bandados encontra-se o flogopita xisto, de granulação fina à média, foliação proeminente, por vezes textura porfiroblástica marcada por cristais

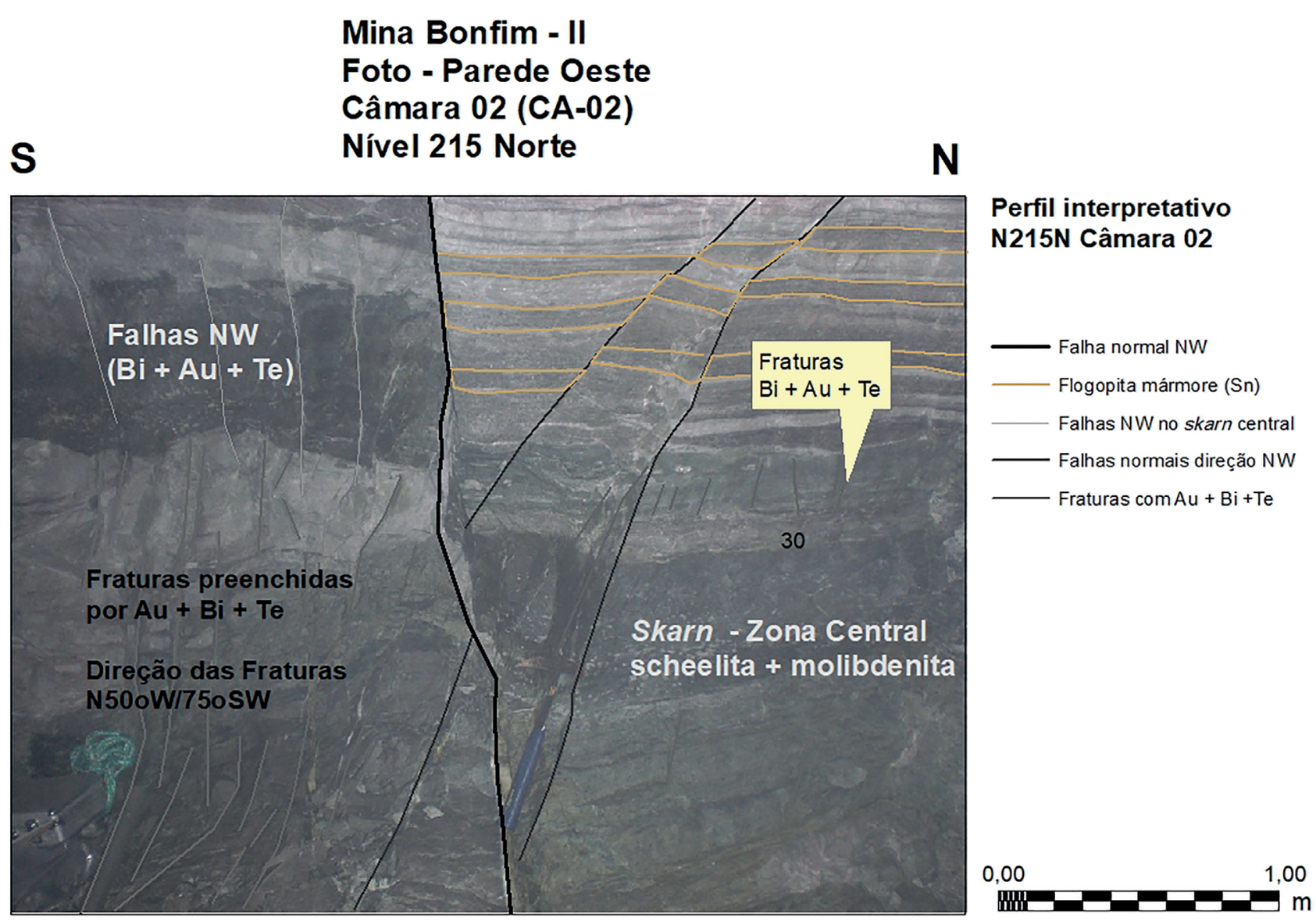

Figura 4. Escarnito com orientação $\mathrm{N} 10^{\circ} \mathrm{E} / 30^{\circ} \mathrm{SE}$, mostrando a zona central máfica mineralizada em scheelita e molibdenita, deslocada por falha de direção NW-SE, que faz parte da família de fraturas subverticais com atitude $\mathrm{N} 50^{\circ} \mathrm{W} / 55^{\circ} \mathrm{SW}$, preenchidas por minerais de bismuto associados à mineralização aurífera, presentes na zona inferior do escarnito. Frente de lavra no nível 215 norte da Mina Bonfim-II. 
de granada (almandina), com diâmetro médio de $1 \mathrm{~cm}$, além de pirrotita, que pode ocorrer tanto disseminada quanto em bolsões milimétricos maciços, ou mais raramente ocupando sombras de pressão de pórfiros de granada.

Além da deformação dúctil a qual foi submetido o corpo de minério bandado rico em scheelita, existe um sistema de estruturas dúctil-rúptil que também afetou o escarnito, sendo representado por falhas direcionais e fraturas de cisalhamento subverticais, dispostas segundo a direção $\mathrm{N} 50^{\circ} \mathrm{W}$ a $\mathrm{N} 70^{\circ} \mathrm{W}$, com mergulho em torno de $75^{\circ} \mathrm{SW}$ (Figura 8G). Essas estruturas são preenchidas predominantemente por prehnita e minerais opacos escuros de bismuto, que estão associados ao ouro, podendo ser vistas em todos os níveis da mina subterrânea seccionando e deslocando a camada máfica (zona central) do escarnito de direção NNE (Figura 7), comprovando o caráter tardio da mineralização aurífera presente nessas estruturas com orientação NW.

Observa-se que as falhas e as fraturas de direção NW à WNW exibem feições de movimento ao longo da direção, de forma paralela às paredes das fraturas, correspondendo a falhas e fraturas de cisalhamento com terminações em splay
(Figura 8H), que definem o controle estrutural da mineralização aurífera. Tais estruturas podem ser classificadas como falhas direcionais sintéticas, pois as terminações são sintéticas em relação à falha principal (Fossen, 2010).

$\mathrm{Na}$ zona inferior do escarnito félsico, é possível observar fraturas preenchidas por bismuto que cortam porções ricas em clinozoizita, de cor rosa-clara, juntamente com epidoto, que correspondem aos minerais que evidenciam a paragênese de baixo grau metamórfico e que caracterizam a fase retrógrada do escarnito, revelando que a mineralização aurífera, além de tardia, é posterior à fase retrógrada do escarnito.

As falhas e as fraturas com bismuto e ouro também podem ser vistas cortando boudins de mármore dentro do escarnito máfico bandado (Figura 8D), mostrando que as fraturas de direção NW e WNW, além de tardias ao metamorfismo e à alteração metassomática que gerou o escarnito (estágio progressivo e retrogrado), também são posteriores à deformação e à boudinagem do escarnito e dos mármores, portanto tardi a pós-tectônicas. Tal fato deixa claro que a mineralização aurífera pertence a uma segunda fase de mineralização. Além disso, a presença de prehnita na

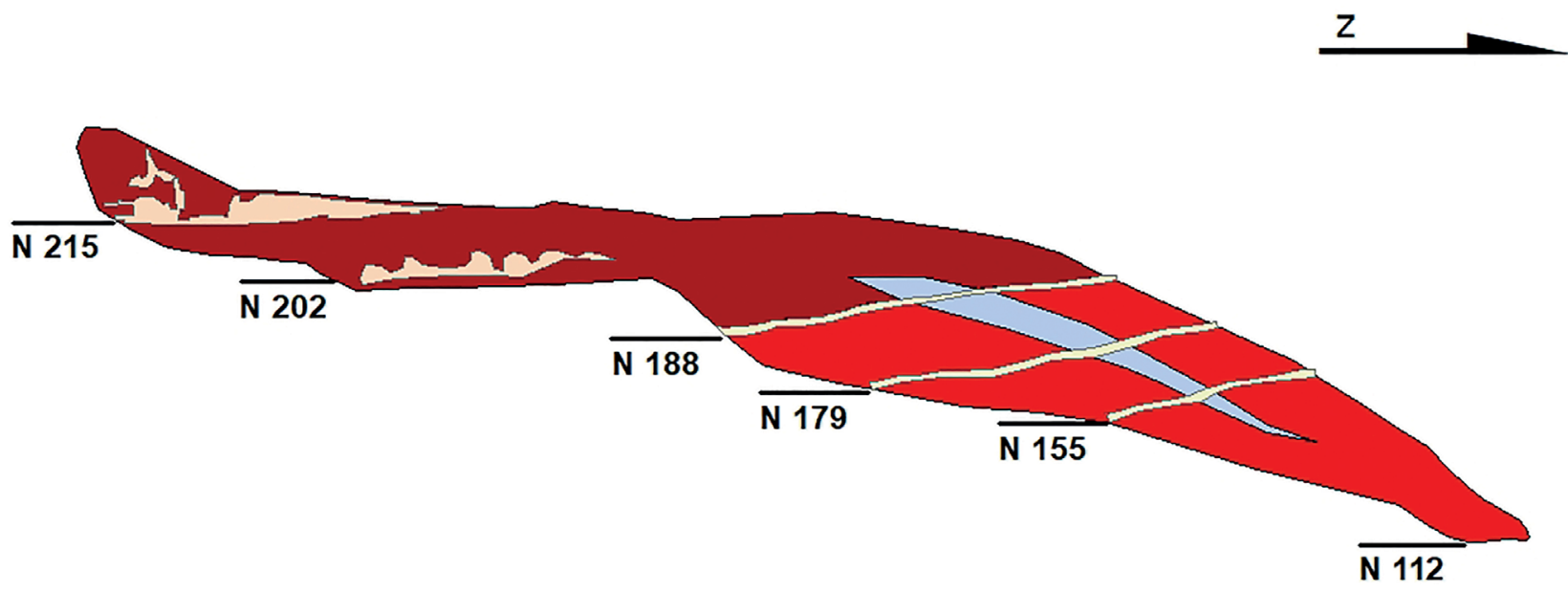

Mina Bonfim - II

Niveis da Mina (Cotas Topográficas)

Galerias Projetadas nos niveis

Escavações / Câmaras e Pilares

Boudin de Mármore Branco

Corpo de Minério com escavações

Corpo de Minério sem escavações

\section{Mineradora Nosso Senhor do Bonfim Mina Bonfim - II Corpo b (minério) - Escarnito Seção Longitudinal}

Escala 1:200

Figura 5. Seção longitudinal do corpo de minério Bonfim-II, modelado no software Surpac (Gemcom) com base no banco de dados de sondagem e em informações de mapeamento estrutural, mostrando a forma de um grande boudin disposto segundo a direção NNE, com plunge de baixo ângulo ao longo de sua direção. Corpo de minério com as escavações dos níveis superiores da mina subterrânea abertos. 


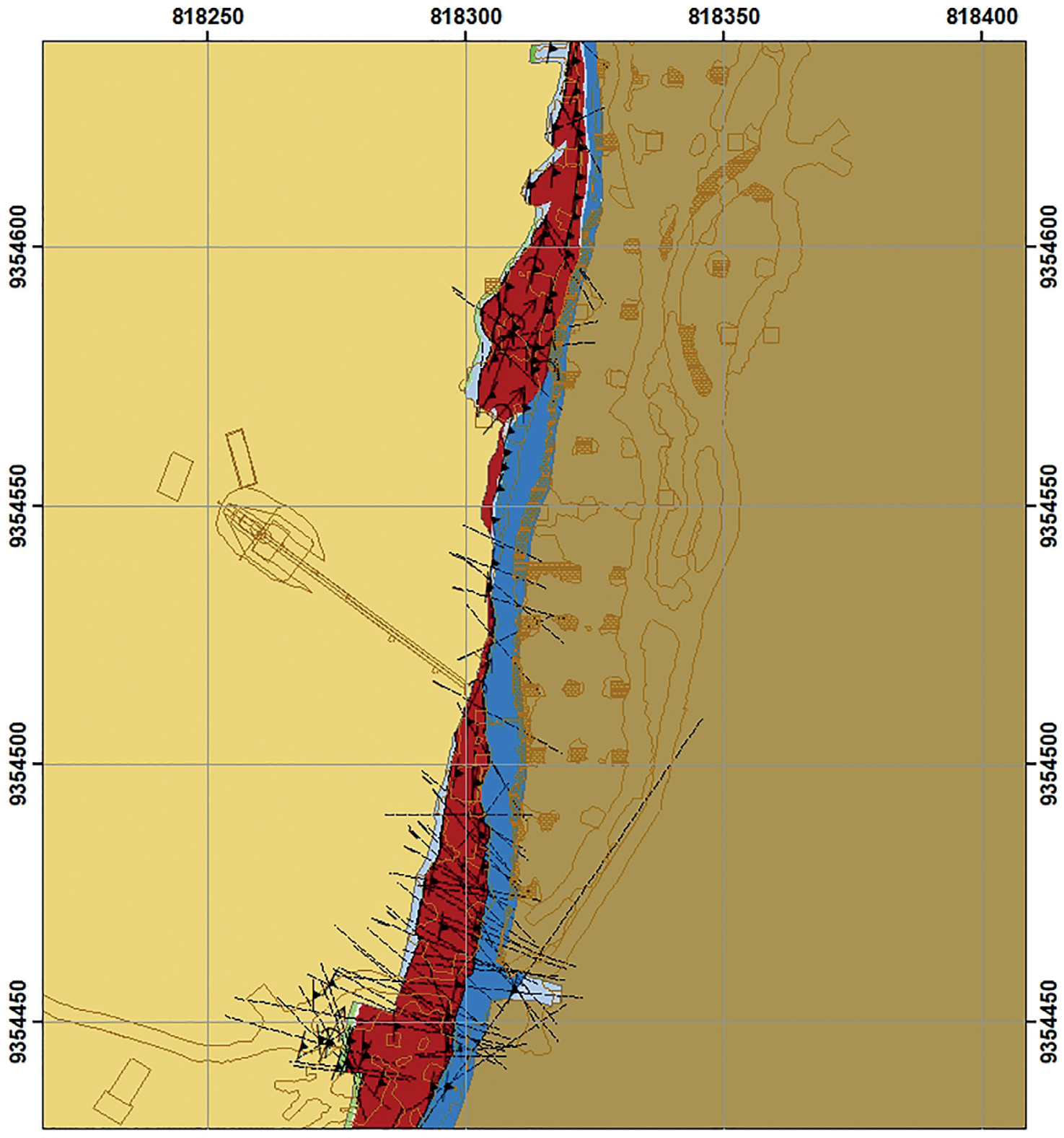

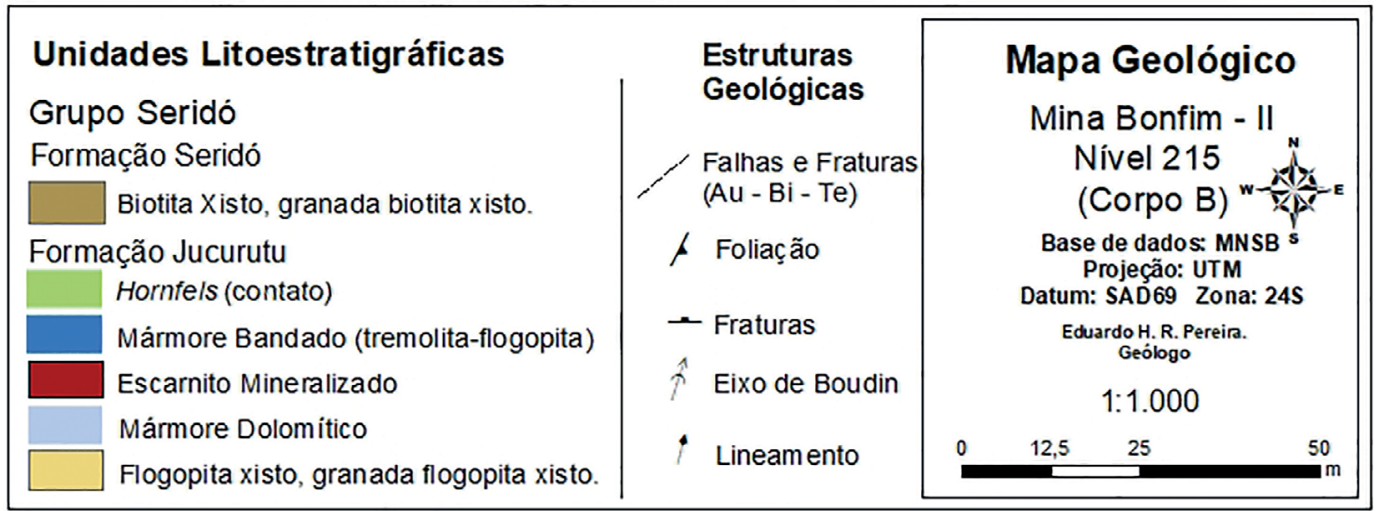

Figura 6. Mapa geológico-estrutural da Mina Bonfim-ll no nível 215, mostrando falhas e fraturas com orientação predominante segundo a direção NW, que correspondem às estruturas mineralizadas em ouro, bismuto e telúrio na mina subterrânea (escala 1:1.000). 


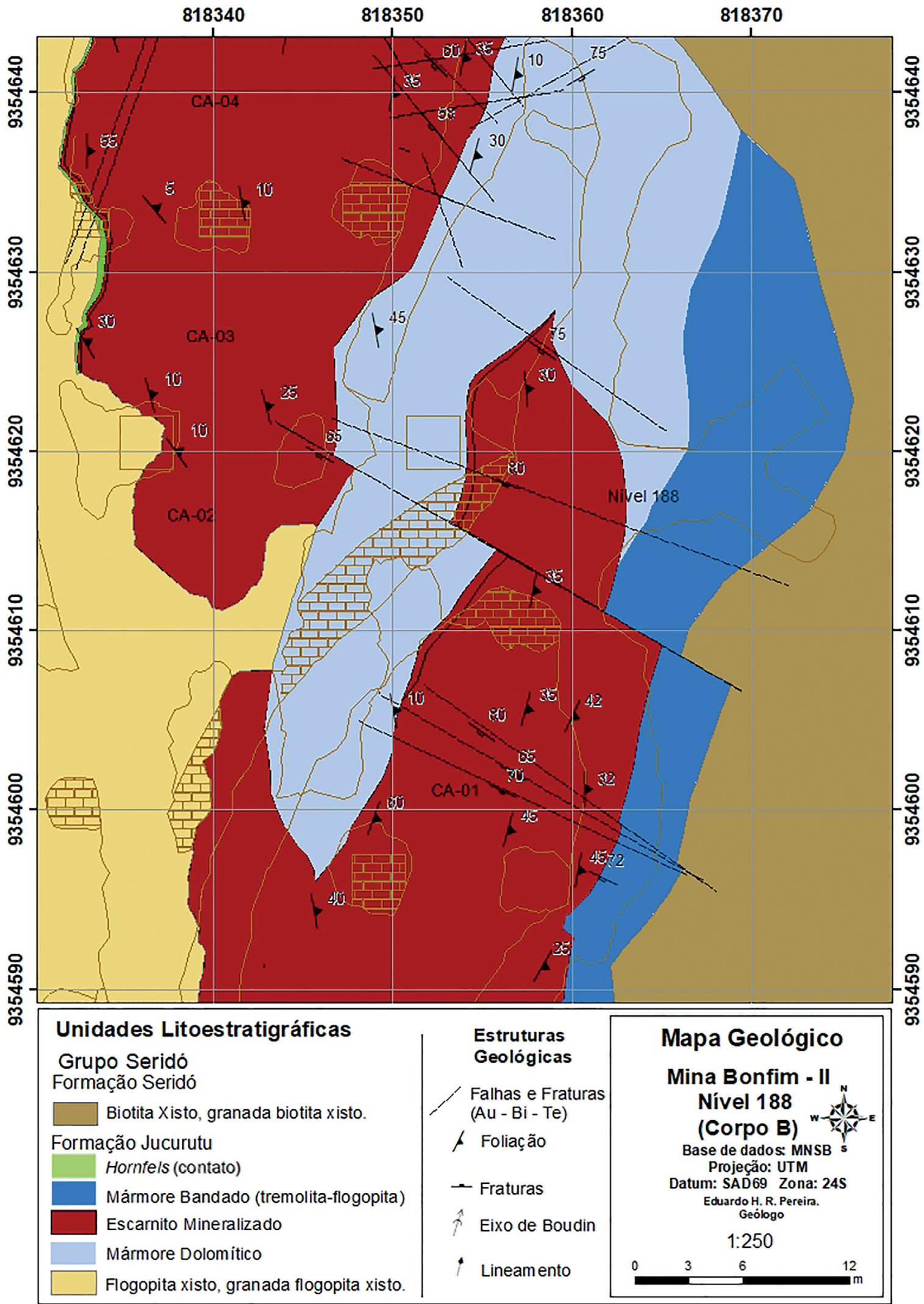

Figura 7. Mapa geológico de detalhe do boudin de mármore branco mapeado na entrada do nível 188. Destacam-se as estruturas, as falhas e as fraturas de direção NW, que controlam a mineralização aurífera. 

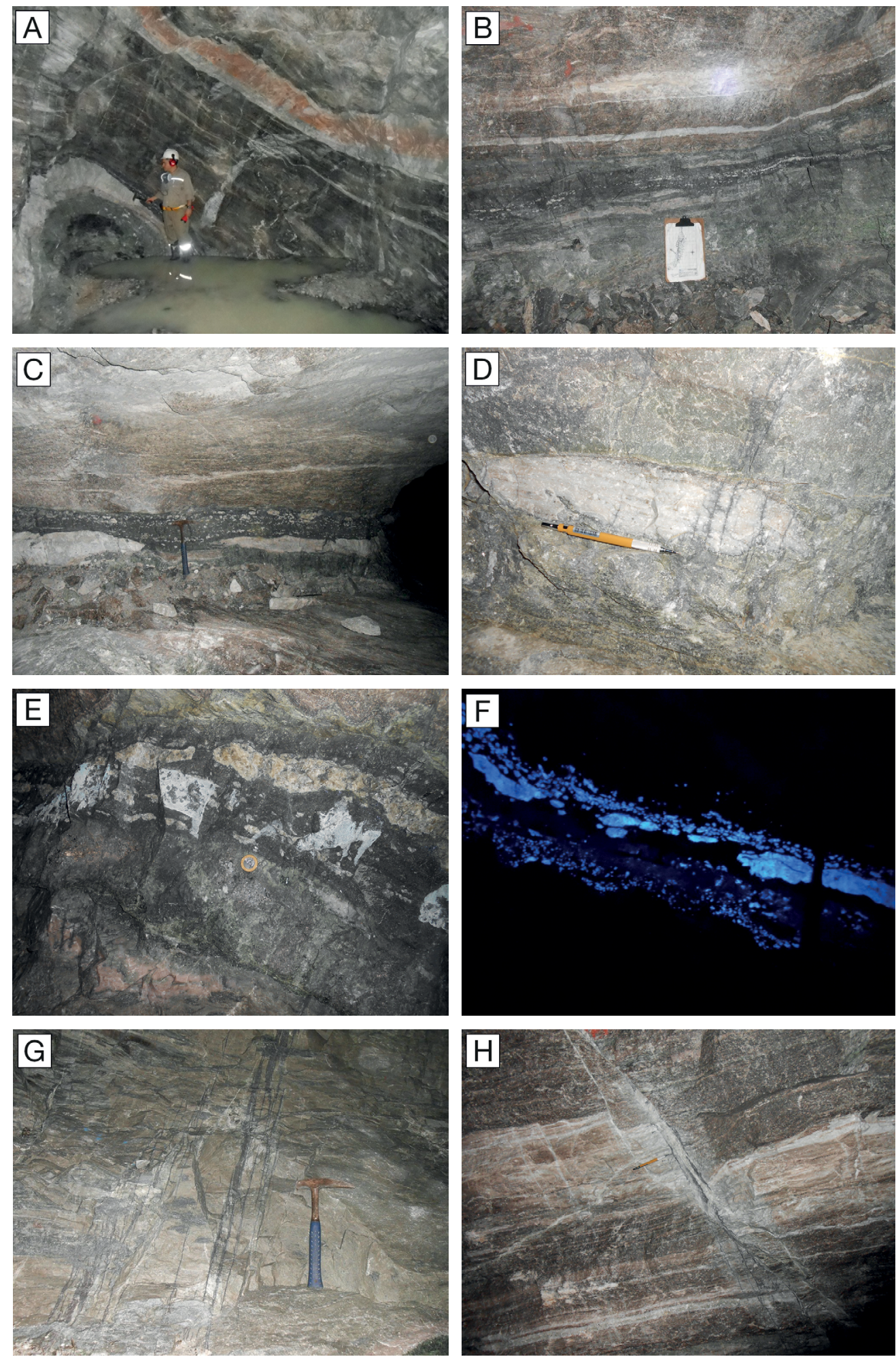

Figura 8. Feições geológicas e estruturas da mina. (A) Mármores bandados acima do escarnito; (B) escarnito no contato entre tremolita-flogopita mármores e flogopita xistos na base; (C) boudins de mármore dolomítico dentro da camada do escarnito; (D) boudin de mármore dolomítico seccionado por fraturas com minerais de bismuto dentro do escarnito; (E) camada de escarnito com boudins de scheelita; (F) boudins de scheelita vistos com luz ultravioleta; (G) fraturas preenchidas por minerais de bismuto preto; $(H)$ falha de direção NW preenchida por minerais de bismuto com terminação em splay na parte inferior. 
ganga indica que a precipitação do ouro ocorreu em fácies prehnita-pumpellyita.

As fraturas preenchidas por bismuto com ouro associado prolongam-se como vênulas praticamente subverticais e paralelas (sheeted veins), abaixo do escarnito máfico, ainda dentro da zona de alteração, podendo chegar até $3 \mathrm{~m}$ abaixo do escarnito máfico, ampliando de modo significativo a espessura da mineralização aurífera.

\section{PETROGRAFIA}

O escarnito formado a partir do metassomatismo associado aos mármores e flogopita xistos constituindo a zona central do corpo de minério principal, rico em scheelita e molibdenita, é classificado como diopsídio escarnito, possuindo granulação fina à média, textura nematoblástica à granoblástica, sendo constituído, predominantemente, de diopsídio, além de actinolita, tremolita, calcita, dolomita, clorita, muscovita e plagioclásio reliquiar.

Os cristais de diopsídio geralmente são milimétricos $(>2$ $\mathrm{mm}$ ), por vezes hipidioblásticos, fortemente fraturados com sericita e carbonato nas fraturas, com inclusões de actinolita, plagioclásio reliquiar, lamelas de clorita, muscovita, e cristais de titanita. $\mathrm{O}$ diopsídio também ocorre sob a forma de subgrãos $(<1 \mathrm{~mm})$ xenoblásticos.

Nota-se que há orientação no escarnito marcada por lamelas de muscovita e clorita juntamente com actinolita entre os grãos de diopsídio, evidenciando a presença de estrutura foliada e/ou bandada na zona central do corpo de minério.

O escarnito originado a partir da alteração de flogopita xistos é de granulação muito fina a afanítica, individualizado na mina como escarnito xistoso, exibindo cor verde-clara, composto de diopsídio de granulação fina $(0,10$ $0,20 \mathrm{~mm})$, clorita, sericita $(<0,1 \mathrm{~mm})$, carbonato, epidoto e zoizita-clinozoizita, que correspondem a minerais da fase retrógrada do escarnito.

A assembleia mineral presente, aliada às texturas e às características da alteração, permite propor que ocorreu intenso processo de alteração de feldspatos gerando sericita, epidoto e calcita, sob condições de fácies xisto verde, durante o metassomatismo e a formação do escarnito.

Lamelas de muscovita e clorita ocorrem de forma orientada, marcando uma direção preferencial, caracterizando uma foliação conspícua na zona inferior do escarnito, a qual aumenta gradativamente em direção ao contato com o flogopita xisto.

Destaca-se a presença de um mineral de cor verde (verde-garrafa), xenoblástico, isotrópico, alto relevo, com tamanhos de $0,25-05,0 \mathrm{~mm}$, disperso em matriz sericítica, raramente encontrado nas lâminas, identificado como granada cromífera (Figura 9A), possivelmente um tipo de granada intermediária entre grossulária e uvarovita.
As fraturas auríferas são constituídas basicamente de prehnita (Figura 9B), minerais opacos de bismuto e telúrio associados, ocorrendo junto às lamelas ou estirados $\mathrm{e}$ preenchendo fraturas e clivagens ao longo das lamelas de prehnita, que comumente coincidem com a direção das fraturas mineralizadas em ouro.

A presença de prehnita, junto à mineralização aurífera em fraturas e veios mineralizados, pode ser considerada um indicativo das condições de metamorfismo durante a precipitação do ouro, que teria ocorrido em fácies metamórfico de grau muito baixo (fácies phrenita-pumpelita), inferior ao grau metamórfico da fase retrógrada do escarnito, caracterizando a segunda fase de mineralização do sistema Au-Bi-Te.

\section{MINEROGRAFIA}

Os principais minerais metálicos identificados ao microscópio, além dos elementos nativos ouro e bismuto, foram: bismutinita, molibdenita, pirrotita, calcopirita e gersdorffita como sulfetos, além dos teluretos de bismuto, joseíta e hedleyita, que compreendem a assembleia de metálicos presentes no escarnito da Mina Bonfim-II. Destaca-se que a gersdorffita e a hedleyita são descritas pela primeira vez em Bonfim.

É característica do ouro exibir refletividade muito alta $(\mathrm{rAu}=83,40 \%)$, contudo os grãos observados possuem cor amarelo-pálido, com menor intensidade, em razão dos elevados teores em prata chegando até $16,09 \% \mathrm{Ag}$ (Tabela 1).

O tamanho dos grãos de ouro compreende diâmetros entre 1 e $20 \mu \mathrm{m}$ (Figura 9), tendo raramente dimensões maiores que $50 \mu \mathrm{m}$, e o maior grão atinge $70 \mu \mathrm{m}$ de diâmetro, mostrando que o ouro é muito fino. As principais formas de ocorrência dos grãos de ouro são ouro livre na ganga (Figura 9C), ouro em contato com bismuto nativo, bismutinita ou joseíta e, por último, ouro em fraturas da ganga.

Os grãos de ouro, quando livres na ganga, podem ocorrer de forma disseminada, como gotículas ou com formas irregulares. $\mathrm{O}$ ouro, quando associado ou em contato com bismuto (bismutinita e joseíta), normalmente tem formas irregulares e variadas, podendo ser encontrado na borda do bismuto (bismutinita e joseíta) ou como inclusão. Quando em fraturas, o ouro encontra-se alongado, assumindo a forma da fratura.

O bismuto ocorre junto com ouro em contato ou em fraturas, fazendo parte da paragênese aurífera (Figura 9D). A bismutinita $\left(\mathrm{Bi}_{2} \mathrm{~S}_{3}\right)$, de composição química $81,3 \% \mathrm{Bi}, 18,7 \% \mathrm{~S}$ (Anthony et al., 1990), é o segundo mineral de bismuto mais abundante associado à mineralização aurífera (Figura 9E). Diferencia-se do bismuto nativo em razão da refletividade mais baixa, conforme pode ser visto na Figura 9F, além de possuir birreflectância distinta.

Observa-se bismutinita de modo intersticial na ganga com dimensões entre 100 e $1.000 \mu \mathrm{m}$, com bismuto nativo 
reliquiar internamente ou nas bordas, comprovando que o sulfeto foi originado a partir do elemento nativo (Figura 9F).

Além de bismuto e bismutinita, encontra-se ainda como parte integrante da paragênese aurífera a joseíta (Figura 9G), que é um telureto de bismuto $\left(\mathrm{Bi}_{4} \mathrm{TeS}_{2}\right)$. Este pode ocorrer tanto disseminado na ganga quanto em fraturas. Encontra-se joseíta em contato com grãos de bismuto nativo (Figura 9H) ou junto à bismutinita, tanto nas bordas quanto internamente, indicando íntima relação de crescimento da joseíta a partir da bismutinita.

Outro telureto de bismuto identificado, porém em menor proporção, é a hedleyita $\left(\mathrm{Bi}_{7} \mathrm{Te}_{3}\right)$, uma vez que o telureto predominante é a joseíta. Presente de forma rara, ainda como integrante da assembleia de sulfetos nos escarnitos, foi determinado um sulfeto de arsênio e níquel cuja composição corresponde à gersdorffita (NiAsS), confirmada por análise de microssonda eletrônica.

Encontra-se comumente outros sulfetos, tais como molibdenita, pirrotita e, subordinadamente, calcopirita. A molibdenita é o sulfeto mais abundante nas seções polidas, contudo deve-se ressaltar que não foram encontrados grãos de ouro associados à molibdenita, não havendo relação paragenética entre ouro e molibdênio.

A pirrotita ocorre de forma disseminada, visível a olho nu, porém não é encontrada junto ao ouro. A calcopirita $\left(\mathrm{CuFeS}_{2}\right)$ está presente de modo subordinado, podendo ser observada nas bordas de cristais de Bi nativo, portanto associada ao ouro.

Deve-se salientar que não foi observado ouro sob a forma de telureto (telureto de ouro), de modo que os grãos de ouro analisados correspondem a ouro livre, em fratura ou em associação com bismuto, sulfetos e teluretos de bismuto, portanto passível de ser recuperado por métodos de beneficiamento para minério de ouro, como cianetação, utilizando lixiviação em pilhas, conforme praticado na Mina Bonfim.

\section{ANÁLISES QUIIMICAS}

Foram identificados por minerografia e confirmados por análises de microssonda eletrônica oito minerais metálicos, presentes nos escarnitos, além do ouro. Minerais de ganga também foram analisados, destacando-se 12 minerais não metálicos entre os 17 silicatos que compõem a ganga, os quais constam da tabela de composição química.

Análises de microssonda eletrônica em grãos de ouro selecionados foram realizadas, obtendo-se a composição média do ouro com $82,34 \% \mathrm{Au}$ e $15,57 \% \mathrm{Ag}$. Observa-se que o ouro possui elevados teores em prata, podendo ter até $16,09 \% \mathrm{Ag}$, o que leva a uma redução aparente na refletividade do ouro, cujos grãos exibem cor amarelo-clara pálida.

Deve-se notar ainda que o ouro possui pequena proporção de bismuto $(0,44 \% \mathrm{Bi})$ em sua composição química, explicitando íntima relação genética. O mesmo é observado em relação ao telúrio, que pode chegar até $0,16 \% \mathrm{Te}$ em grãos de ouro (Tabela 1).

Análises químicas em testemunhos de sondagem de escarnitos mostram que elevados teores em ouro ( $>10 \mathrm{ppm} \mathrm{Au})$ normalmente estão relacionados a altos teores em bismuto

Tabela 1. Resultados das análises químicas de microssonda eletrônica em grãos de ouro do escarnito.

\begin{tabular}{lcccccccccccc}
\hline Análises & Au1 & Au2 & Au3 & Au4 & Au5 & Au6 & Au7 & Au8 & Au9 & Au10 & Au11 & Au12 \\
\hline $\mathrm{Bi}(\mathrm{wt} \%)$ & 0,00 & 0,00 & 0,22 & 0,44 & 0,37 & 0,33 & 0,20 & 0,37 & 0,18 & 0,40 & 0,39 & 0,31 \\
$\mathrm{Fe}$ & 0,20 & 0,10 & 0,06 & 0,00 & 0,01 & 0,00 & 0,04 & 0,02 & 0,02 & 0,05 & 0,05 & 0,07 \\
$\mathrm{Cu}$ & 0,07 & 0,08 & $\mathrm{na}$ & 0,01 & 0,01 & 0,01 & 0,04 & 0,02 & 0,01 & 0,00 & 0,00 & 0,00 \\
$\mathrm{Ag}$ & 15,41 & 15,50 & 16,09 & 15,79 & 15,82 & 15,67 & 15,42 & 15,12 & 14,98 & 15,57 & 15,70 & 15,75 \\
$\mathrm{Te}$ & 0,00 & 0,06 & 0,06 & 0,07 & 0,00 & 0,04 & 0,16 & 0,07 & 0,06 & 0,06 & 0,03 & 0,09 \\
$\mathrm{~S}$ & 0,01 & 0,00 & 0,02 & 0,00 & 0,01 & 0,01 & 0,01 & 0,00 & 0,00 & 0,03 & 0,02 & 0,04 \\
$\mathrm{Mo}$ & 0,24 & 0,25 & 0,00 & 0,00 & 0,00 & 0,00 & 0,00 & 0,00 & 0,00 & 0,00 & 0,00 & 0,00 \\
$\mathrm{Au}$ & 80,92 & 81,36 & 83,33 & 81,90 & 81,93 & 83,44 & 82,68 & 83,20 & 83,20 & 81,67 & 82,15 & 82,35 \\
Total & 97,03 & 97,35 & 99,77 & 98,25 & 98,15 & 99,68 & 98,62 & 98,91 & 98,48 & 97,89 & 98,39 & 98,65 \\
\hline $\mathrm{Bi}(\mathrm{at} \%)$ & 0,00 & 0,00 & $\mathrm{nc}$ & $\mathrm{nc}$ & $\mathrm{nc}$ & $\mathrm{nc}$ & $\mathrm{nc}$ & $\mathrm{nc}$ & $\mathrm{nc}$ & $\mathrm{nc}$ & $\mathrm{nc}$ & $\mathrm{nc}$ \\
$\mathrm{Fe}$ & $\mathrm{nc}$ & $\mathrm{nc}$ & $\mathrm{nc}$ & 0,00 & $\mathrm{nc}$ & 0,00 & $\mathrm{nc}$ & $\mathrm{nc}$ & $\mathrm{nc}$ & $\mathrm{nc}$ & $\mathrm{nc}$ & $\mathrm{nc}$ \\
$\mathrm{Cu}$ & $\mathrm{nc}$ & $\mathrm{nc}$ & $\mathrm{nc}$ & $\mathrm{nc}$ & $\mathrm{nc}$ & $\mathrm{nc}$ & $\mathrm{nc}$ & 0,00 & 0,00 & 0,00 & $\mathrm{nc}$ & 0,00 \\
$\mathrm{Ag}$ & 0,25 & 0,25 & 0,26 & 0,26 & 0,26 & 0,25 & 0,25 & 0,25 & 0,24 & 0,26 & 0,26 & 0,26 \\
$\mathrm{Te}$ & 0,00 & $\mathrm{nc}$ & $\mathrm{nc}$ & $\mathrm{nc}$ & 0,00 & $\mathrm{nc}$ & $\mathrm{nc}$ & $\mathrm{nc}$ & $\mathrm{nc}$ & $\mathrm{nc}$ & $\mathrm{nc}$ & $\mathrm{nc}$ \\
$\mathrm{S}$ & $\mathrm{nc}$ & 0,00 & $\mathrm{nc}$ & 0,00 & $\mathrm{nc}$ & $\mathrm{nc}$ & $\mathrm{nc}$ & 0,00 & 0,00 & $\mathrm{nc}$ & $\mathrm{nc}$ & $\mathrm{nc}$ \\
$\mathrm{Mo}$ & $\mathrm{nc}$ & $\mathrm{nc}$ & 0,00 & 0,00 & 0,00 & 0,00 & 0,00 & 0,00 & 0,00 & 0,00 & 0,00 & $\mathrm{nc}$ \\
$\mathrm{Au}$ & 0,73 & 0,73 & 0,74 & 0,74 & 0,74 & 0,74 & 0,75 & 0,75 & 0,75 & 0,74 & 0,74 & 0,74 \\
Total & 0,98 & 0,98 & 1,00 & 1,00 & 1,00 & 0,99 & 1,00 & 1,00 & 0,99 & 1,00 & 1,00 & 1,00 \\
\hline
\end{tabular}

nc: não calculado; na: não analisado. 

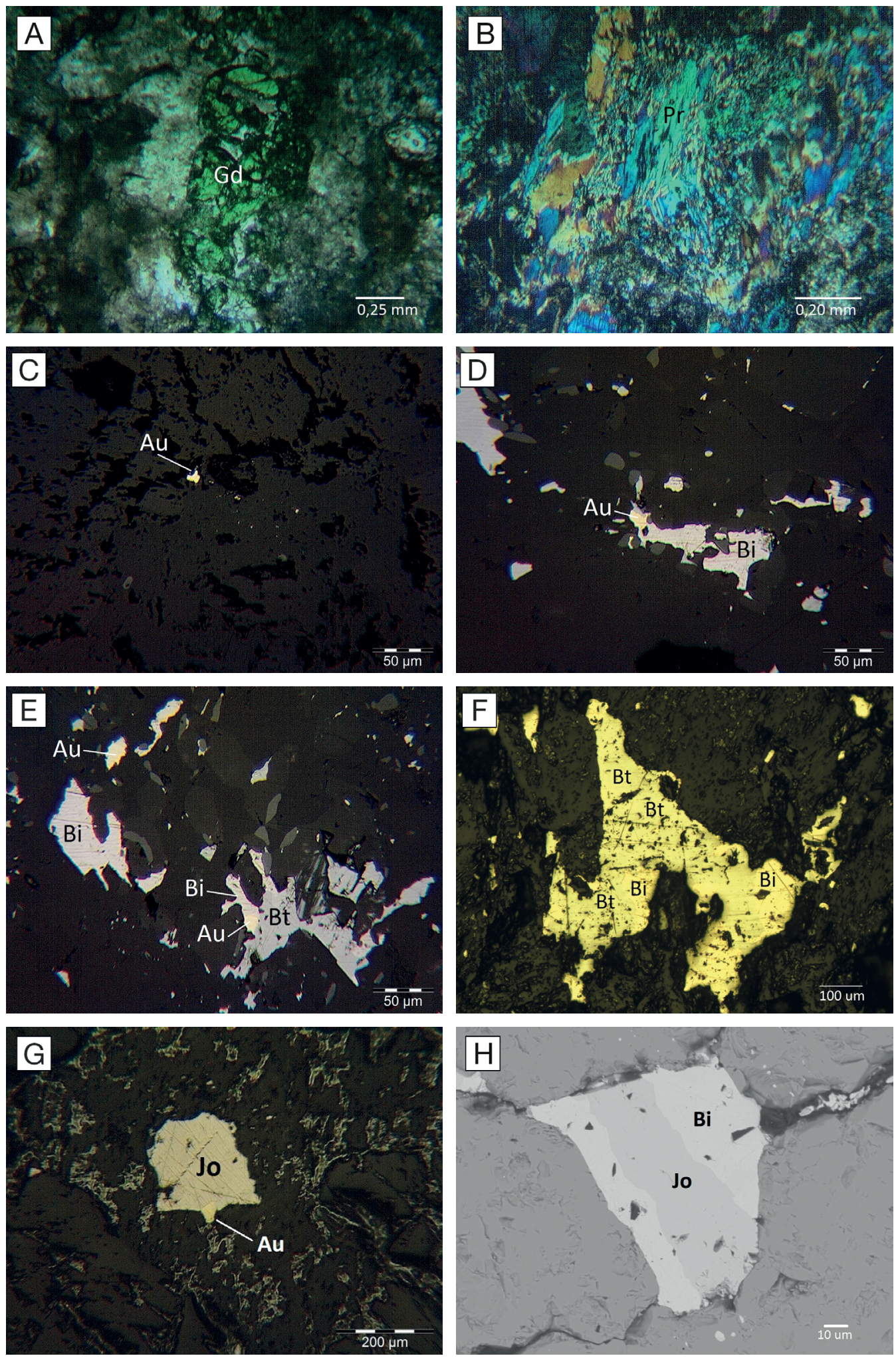

Gd: granada; Pr: prehnita; Au: ouro; Bi: bismuto; Bt: bismutinita; Jo: joseíta. Aumento = ocular $\times$ objetiva: 40X.

Figura 9. Fotomicrografias de amostras de escarnitos da Mina Bonfim-II. (A) Granada cromífera de cor verde, N// - 40X; (B) lamelas de prehnita, NX - 100X; (C) ouro livre na ganga; (D) ouro em contato com bismuto, 400X; (E) ouro em contato com bismuto e bismutinita, 400X; (F) bismutinita com bismuto nas bordas, 100X; (G) ouro em contato com joseíta, 200X; $(\mathrm{H})$ joseíta associada com bismuto (microscópio eletrônico de varredura - MEV). 
e telúrio (Tabela 2), comprovando quimicamente a associação entre os elementos.

A tabela de composição química mostra que o bismuto nativo é composto praticamente de bismuto, apresentando praticamente $99 \% \mathrm{Bi}$, tendo ainda pequenas proporções de $\mathrm{Fe}, \mathrm{Cu}, \mathrm{Ag}$ e Se, respectivamente, em que se destaca o teor de selênio, que chega até $0,21 \%$ Se nos grãos de bismuto (Tabela 3). Nota-se que não foi detectado selênio na bismutinita, o qual deveria fazer parte de sua composição química. Além disso, também estão ausentes $\mathrm{Pb}, \mathrm{Fe}$ e $\mathrm{Te}$, os quais também deveriam fazer parte da composição.

O principal sulfeto que integra a paragênese aurífera é a bismutinita, que tem em média $80 \% \mathrm{Bi}$, e em menores proporções, enxofre e cobre, este em pequena proporção $(0,16 \% \mathrm{Cu})$, o que pode ser admitido com base na fórmula química da bismutinita, conforme determinado por Anthony et al. (1990).

Por outro lado, cristais de calcopirita analisados chegam a ter até $0,32 \% \mathrm{Bi}$ composicionalmente, o que não é comum para a calcopirita, evidenciando enriquecimento em bismuto, o que leva a incluir esse sulfeto na paragênese aurífera.

As análises de bismutinita revelam pequeno percentual de molibdênio em sua composição química, atingindo até 0,37\% Mo (Tabela 3), o que não faz parte da composição química estabelecida para a bismutinita, podendo refletir contaminação.

Resultados de análises mostram que pode ser encontrado até $0,61 \%$ Bi na composição de cristais de molibdenita, podendo estar relacionado a pequenas fraturas tardias, ricas em $\mathrm{Bi}$, que cortam porções do escarnito com molibdenita.

Quanto aos teluretos de bismuto, observa-se que há ligeiro empobrecimento em Te na joseíta (10,26\% Te), considerando os valores de telúrio determinados para a joseíta (Anthony et al., 1990), que variam de 12,00 a $15,93 \%$ Te. Além disso, a hedleyita pode apresentar até $21,42 \% \mathrm{Te}$ (Tabela 3 ), sendo o mineral mais rico em telúrio no escarnito.

As proporções de selênio nos teluretos analisados variam de 0,32 a $0,37 \%$ Se (Tabela 3 ), o que é normal para a hedleyita, contudo para a joseíta é um valor baixo, indicando deficiência em selênio, uma vez que os valores da literatura, conforme Anthony et al. (1990), são da ordem de 1,48 a $2,84 \%$ Se para a joseíta.

Os dados obtidos com as análises de pirrotita mostram que ela apresenta pequena deficiência em ferro $(58,83 \% \mathrm{Fe}) \mathrm{em}$ relação à composição ideal registrada na literatura (Anthony et al., 1990), que é de $62,33 \%$ de Fe para $37,67 \%$ de S.

Análises pontuais de microssonda foram feitas na ganga, que é composta, predominantemente, de diopsídio. Observa-se que o diopsídio apresenta baixo teor de magnésio (Tabela 4) quando comparado com os teores determinados por Anthony et al. (1990). Elevados teores de ferro $(6,69 \% \mathrm{FeO})$ presente em diopsídio provavelmente podem indicar condições de formação e/ou alteração do escarnito em ambiente reduzido.

Os minerais cálcicos presentes na assembleia mineralógica do escarnito são diopsídio, actinolita e tremolita

Tabela 2. Resultados de análises químicas de testemunhos de sondagem de escarnitos.

\begin{tabular}{|c|c|c|c|c|c|c|c|c|c|c|c|c|c|}
\hline $\begin{array}{l}\text { Furos } \\
\text { Sonda }\end{array}$ & $\begin{array}{l}\text { Prof. } \\
\text { De }(m)\end{array}$ & $\begin{array}{c}\text { Prof. } \\
\text { Até }(\mathrm{m})\end{array}$ & $\begin{array}{c}\text { Interval } \\
\text { metros }\end{array}$ & $\begin{array}{c}\text { Amostra } \\
\text { Id \# }\end{array}$ & $\begin{array}{c}\mathrm{Au} \\
\mathrm{ppm}\end{array}$ & $\begin{array}{c}\mathrm{Ag} \\
\mathrm{ppm}\end{array}$ & $\begin{array}{l}\mathrm{Bi} \\
\% \\
\end{array}$ & $\begin{array}{c}\mathrm{Cu} \\
\mathrm{ppm}\end{array}$ & $\begin{array}{c}\mathrm{Fe} \\
\% \\
\end{array}$ & $\begin{array}{c}\mathrm{Hg} \\
\mathrm{ppm}\end{array}$ & $\begin{array}{c}\text { Mo } \\
\text { ppm }\end{array}$ & $\begin{array}{c}\mathrm{Te} \\
\mathrm{ppm}\end{array}$ & $\begin{array}{c}\mathrm{WO}_{3} \\
\%\end{array}$ \\
\hline SEB10 & 80,81 & 81,31 & 0,50 & 10833 & 3,72 & 1,25 & 0,12 & 88,7 & 1,87 & 0,12 & 11,15 & 29,46 & 2,26 \\
\hline SEB11 & 58,46 & 58,98 & 0,52 & 10839 & 4,24 & 1,01 & 0,13 & 3,70 & 1,49 & 0,01 & 2,12 & 44,05 & 0,00 \\
\hline SEB15 & 34,73 & 35,19 & 0,46 & 10906 & 5,50 & 1,58 & 0,15 & 15,1 & 0,78 & 0,01 & 1,00 & 42,81 & 0,00 \\
\hline SEB21 & 1,70 & 2,45 & 0,75 & 10965 & 27,13 & 4,47 & 0,99 & 9,10 & 0,57 & 0,02 & 1,29 & 364,4 & 0,75 \\
\hline SEB25 & 122,10 & 122,27 & 0,17 & 11017 & 49,39 & 8,66 & 1,00 & 29,8 & 0,88 & 2,34 & 24,93 & 528,0 & 2,79 \\
\hline SEB27 & 71,13 & 71,60 & 0,47 & 11053 & 13,57 & 3,57 & 0,39 & 4,90 & 1,23 & 0,01 & 2,41 & 107,8 & 0,00 \\
\hline SEB100 & 96,41 & 96,91 & 0,50 & 11150 & 23,82 & 7,54 & 0,91 & 27,7 & 0,81 & 1,32 & 14,73 & 273,4 & 0,63 \\
\hline SEB100 & 96,91 & 97,62 & 0,71 & & 14,75 & 4,43 & 0,49 & 4,10 & 0,80 & 0,01 & 2,77 & 69,96 & 0,02 \\
\hline SEB101 & 110,65 & 111,21 & 0,56 & 11304 & 13,05 & 2,96 & 0,40 & 3,10 & 0,90 & 0,01 & 4,38 & 122,3 & 0,01 \\
\hline SEB101 & 114,93 & 115,38 & 0,45 & 11306 & 11,92 & 3,66 & 0,33 & 396 & 0,66 & 0,01 & 1,60 & 91,60 & 0,01 \\
\hline SEB101 & 121,33 & 122,00 & 0,67 & 11308 & 2,85 & 1,29 & 0,08 & 17,3 & 1,07 & 0,07 & 3,08 & 22,79 & 0,04 \\
\hline SEB45 & 5,45 & 6,40 & 0,95 & 11348 & 9,91 & 1,91 & 0,36 & 106 & 0,96 & 0,01 & 0,67 & 94,93 & 0,00 \\
\hline SEB46 & 9,50 & 10,00 & 0,50 & 11352 & 16,80 & 4,34 & 0,55 & 8,30 & 0,38 & 0,01 & 0,76 & 144,4 & 0,00 \\
\hline SEB107 & 90,63 & 91,00 & 0,37 & 11357 & 23,77 & 3,81 & 0,65 & 4,40 & 0,54 & 0,04 & 5,16 & 221,9 & 0,00 \\
\hline SEB107 & 91,00 & 91,40 & 0,40 & 11358 & 3,36 & 1,20 & 0,10 & 5,90 & 0,90 & 0,01 & 1,20 & 6,49 & 0,01 \\
\hline SEB107 & 94,43 & 95,32 & 0,89 & 11364 & 4,00 & 0,47 & 0,08 & 91,2 & 1,84 & 0,01 & 1,33 & 19,61 & 0,00 \\
\hline SEB112 & 83,67 & 84,50 & 0,83 & 11405 & 18,51 & 4,93 & 0,62 & 29,1 & 0,48 & 1,68 & 147,1 & 185,4 & 2,78 \\
\hline SEB125 & 87,52 & 87,98 & 0,46 & 11476 & 15,16 & 3,20 & 0,50 & 3,50 & 0,49 & 1,93 & 355,3 & 193,1 & 3,43 \\
\hline
\end{tabular}

SEB: Sistema Estrutural Bonfim; métodos analíticos/laboratórios: Au: Fire Assay (50g)/Laboratório da Mina Nosso Senhor do Bonfim (LMNSB), Lajes, Rio Grande

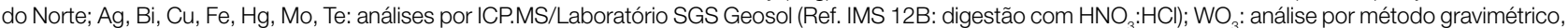
dissolução com HCl, $\mathrm{HNO}_{3}, \mathrm{NH}_{4} \mathrm{Cl}$ e NH $\mathrm{NH}_{4} \mathrm{OH} / \mathrm{LMNSB}$. OP LAB 021; SGS Geosol - Certificado de Análises GQ1004402. 
(Tabela 4). A predominância de minerais cálcicos na ganga aponta para um escarnito cálcico e com baixo teor na molécula Tschermark nos anfibólios.

\section{DISCUSSÃO E COMENTÁRIOS}

As Minas Bonfim-I e II, incluindo o depósito Bonfim-III, presentes no trend estrutural de direção NNE-SSW, correspondem estruturalmente a corpos de escarnitos boudinados que constituem o SEB (Figura 10).

Os furos de sonda que definem o depósito Bonfim-III exibem elevados teores de $\mathrm{Au}$ e $\mathrm{WO}_{3}$, equivalentes aos de Bonfim-II, além de valores anômalos em Mo, Bi e Te, demonstrando que pode vir a se tornar um depósito viável economicamente, assim como foi a Mina Bonfim-II. Considerando as observações da Mina Bonfim-II, aliadas às informações presentes na literatura sobre Bonfim-I, pode-se tecer alguns comentários.
As estruturas principais dispostas segundo a direção NNE-SSW e verticalizadas encontradas em Bonfim, notadamente as transcorrências, os bandamentos e as foliações, correspondem à estruturação dos xistos Seridó, ou seja, tipicamente brasiliana e correlacionável à fase D3 de Jardim de Sá (1984, 1994). Desse modo, em termos estruturais à formação da mineralização de tungstênio (scheelita) e molibdênio no escarnito, estaria associado à fase D3.

A mineralização aurífera na Mina Bonfim-II encontra-se nitidamente controlada por falhas e fraturas de cisalhamento de direção WNW-ESE, constituídas de minerais de bismuto e telúrio preenchendo fraturas junto com prehnita, apresentando caráter tardio, pois cortam a camada principal do escarnito bandado de direção NNE-SSW. Desse modo, as falhas direcionais e as fraturas de cisalhamento podem ser correlacionadas à quarta fase de deformação (D4), definida como uma estrutura de fraca intensidade disposta segundo o trend NW-SE (Hackspacher e Sá, 1984).

Tabela 3. Minerais metálicos analisados em amostras de escarnitos (Corpo B) da Mina Bonfim-II.

\begin{tabular}{|c|c|c|c|c|c|c|c|c|}
\hline Análises & Bismuto & Bismutinita & Joseíta & Hedleyita & Molibdenita & Gersdorffita & Pirrotita & Calcopirita \\
\hline $\mathrm{Bi}(\mathrm{wt} \%)$ & 99,66 & 80,41 & 83,04 & 77,42 & 0,61 & 0,04 & 0,11 & 0,32 \\
\hline $\mathrm{Fe}$ & 0,00 & 0,00 & 0,09 & 0,03 & 0,00 & 6,91 & 58,83 & 29,26 \\
\hline $\mathrm{Cu}$ & 0,04 & 0,16 & 0,07 & 0,00 & 0,00 & 0,04 & 0,02 & 33,61 \\
\hline $\mathrm{Pb}$ & 0,00 & 0,00 & 0,33 & 0,00 & 0,18 & 0,00 & 0,10 & 0,20 \\
\hline $\mathrm{Ni}$ & 0,01 & 0,06 & 0,00 & 0,00 & 0,02 & 28,40 & 0,12 & 0,00 \\
\hline Co & 0,00 & 0,00 & 0,05 & 0,00 & 0,01 & 0,22 & 0,10 & 0,06 \\
\hline $\mathrm{Ag}$ & 0,05 & 0,01 & 0,01 & 0,00 & 0,02 & 0,02 & 0,00 & 0,00 \\
\hline $\mathrm{Se}$ & 0,21 & 0,00 & 0,32 & 0,37 & 0,00 & 0,00 & 0,03 & 0,00 \\
\hline $\mathrm{Te}$ & 0,00 & 0,00 & 10,26 & 21,42 & 0,00 & 0,05 & 0,00 & 0,03 \\
\hline As & 0,00 & 0,00 & 0,00 & 0,02 & 0,00 & 47,26 & 0,00 & 0,00 \\
\hline$S$ & 0,00 & 18,73 & 6,44 & 0,00 & 40,18 & 17,92 & 39,98 & 34,98 \\
\hline Mo & 0,00 & 0,37 & 0,00 & 0,00 & 59,88 & 0,00 & 0,00 & 0,04 \\
\hline $\mathrm{Au}$ & 0,00 & 0,00 & 0,00 & 0,00 & 0,00 & 0,00 & 0,00 & 0,00 \\
\hline Total & 99,96 & 99,75 & 100,60 & 99,25 & 100,88 & 100,84 & 99,28 & 98,49 \\
\hline $\mathrm{Bi}$ (at\%) & 1,00 & 1,97 & 3,99 & 6,82 & $\mathrm{nc}$ & $\mathrm{Nc}$ & $\mathrm{nc}$ & 0,00 \\
\hline $\mathrm{Fe}$ & 0,00 & 0,00 & $\mathrm{nc}$ & $\mathrm{Nc}$ & 0,00 & 0,20 & 1,35 & 0,97 \\
\hline $\mathrm{Cu}$ & $\mathrm{nc}$ & 0,01 & $\mathrm{nc}$ & 0,00 & 0,00 & Nc & $\mathrm{nc}$ & 0,98 \\
\hline $\mathrm{Pb}$ & 0,00 & 0,00 & 0,01 & 0,00 & nc & 0,00 & $\mathrm{nc}$ & nc \\
\hline $\mathrm{Ni}$ & $\mathrm{nc}$ & $\mathrm{nc}$ & 0,00 & 0,00 & $\mathrm{nc}$ & 0,80 & $\mathrm{nc}$ & 0,00 \\
\hline Co & 0,00 & 0,00 & $\mathrm{nc}$ & 0,00 & $\mathrm{nc}$ & $\mathrm{Nc}$ & $\mathrm{nc}$ & $\mathrm{nc}$ \\
\hline $\mathrm{Ag}$ & $\mathrm{nc}$ & $\mathrm{nc}$ & $\mathrm{nc}$ & 0,00 & $\mathrm{nc}$ & $\mathrm{Nc}$ & 0,00 & 0,00 \\
\hline $\mathrm{Se}$ & $\mathrm{nc}$ & 0,00 & 0,16 & 0,08 & 0,00 & 0,00 & $\mathrm{nc}$ & 0,00 \\
\hline $\mathrm{Te}$ & $\mathrm{nc}$ & 0,00 & 0,80 & 3,09 & 0,00 & $\mathrm{Nc}$ & 0,00 & $\mathrm{nc}$ \\
\hline As & $\mathrm{nc}$ & 0,00 & 0,00 & $\mathrm{Nc}$ & 0,00 & 1,05 & 0,00 & 0,00 \\
\hline$S$ & $\mathrm{nc}$ & 2,99 & 2,01 & 0,00 & 2,00 & 0,93 & 1,59 & 2,03 \\
\hline Mo & $\mathrm{nc}$ & 0,02 & 0,00 & 0,00 & 0,99 & 0,00 & 0,00 & $\mathrm{nc}$ \\
\hline $\mathrm{Au}$ & nc & 0,00 & 0,00 & 0,00 & 0,00 & 0,00 & 0,00 & 0,00 \\
\hline Total & 1,00 & 5,00 & 6,97 & 9,99 & 2,99 & 2,98 & 2,94 & 3,98 \\
\hline
\end{tabular}

nc: não calculado. 
Pegmatitos presentes na região de Bonfim, incluindo diques pegmatíticos mapeados imediatamente a oeste e a sul da Mina Bonfim-II (Figura 3), ocorrem dispostos segundo a direção $\mathrm{N} 60^{\circ} \mathrm{W} / 60^{\circ} \mathrm{NE}$, correspondendo praticamente à mesma direção em que se encontram as estruturas mineralizadas em ouro e bismuto na Mina Bonfim-II. Desse modo, considera-se, neste trabalho, que os pegmatitos sejam os responsáveis pela fonte de calor e fluidos que proporcionaram a formação da mineralização aurífera (Figura 11), uma vez que representam o último magmatismo tardi-orogênico na Província Borborema.

Tabela 4. Minerais não metálicos analisados por microssonda eletrônica em amostras de escarnitos (Corpo B) da Mina Bonfim-II.

\begin{tabular}{|c|c|c|c|c|c|c|c|c|c|c|c|c|}
\hline Análises & Plagioclásio & $\mathrm{K}-\mathrm{F}$ & Diopsídio & Actinolita & Tremolita & $\begin{array}{c}\text { Zoizita- } \\
\text { clinozoizita }\end{array}$ & Allanita & Titanita & Clorita & Muscovita & Apatita & Calcita \\
\hline $\mathrm{SiO}_{2}(\mathrm{wt} \%)$ & 57,04 & 64,05 & 53,23 & 55,70 & 55,78 & 40,76 & 34,94 & 30,03 & 27,98 & 47,30 & 0,06 & 0,03 \\
\hline $\mathrm{TiO}_{2}$ & 0,08 & 0,09 & 0,07 & 0,10 & 0,02 & 0,00 & 0,00 & 35,51 & 0,04 & 0,03 & 0,01 & 0,00 \\
\hline $\mathrm{Al}_{2} \mathrm{O}_{3}$ & 27,84 & 19,09 & 0,24 & 2,13 & 0,79 & 35,18 & 25,62 & 2,31 & 21,08 & 38,00 & 0,01 & 0,00 \\
\hline $\mathrm{FeO}$ & 0,06 & 0,02 & 6,69 & 9,18 & 4,17 & 0,00 & 6,22 & 0,18 & 12,60 & 0,38 & 0,01 & 0,12 \\
\hline $\mathrm{MnO}$ & 0,00 & 0,03 & 0,85 & 0,49 & 0,22 & 0,05 & 0,23 & 0,08 & 0,50 & 0,02 & 0,05 & 0,24 \\
\hline $\mathrm{MgO}$ & 0,00 & 0,00 & 14,20 & 18,79 & 22,03 & 0,01 & 0,55 & 0,00 & 25,65 & 0,81 & 0,02 & 0,04 \\
\hline $\mathrm{CaO}$ & 5,69 & 0,05 & 24,42 & 12,40 & 13,96 & 23,55 & 19,15 & 29,53 & 0,03 & 0,15 & 55,61 & 55,81 \\
\hline $\mathrm{Na}_{2} \mathrm{O}$ & 5,65 & 0,20 & 0,09 & 0,20 & 0,00 & 0,30 & 0,00 & 0,00 & 0,00 & 0,12 & 0,01 & 0,01 \\
\hline $\mathrm{K}_{2} \mathrm{O}$ & 3,74 & 15,77 & 0,00 & 0,09 & 0,07 & 0,01 & 0,02 & 0,00 & 0,03 & 10,64 & 0,01 & 0,01 \\
\hline $\mathrm{P}_{2} \mathrm{O}_{5}$ & 0,00 & 0,04 & 0,00 & 0,00 & 0,00 & 0,00 & 0,00 & 0,00 & 0,00 & 0,00 & 42,57 & 0,00 \\
\hline $\mathrm{F}$ & 0,00 & 0,00 & 0,00 & 0,00 & 0,00 & 0,00 & 0,00 & 0,00 & 0,00 & 0,78 & 3,34 & 0,00 \\
\hline $\mathrm{Cl}$ & 0,00 & 0,00 & 0,00 & 0,00 & 0,00 & 0,00 & 0,00 & 0,00 & 0,00 & 0,01 & 0,06 & 0,00 \\
\hline $\mathrm{O} \equiv(\mathrm{F}+\mathrm{Cl})$ & & & & & & & & & & $-0,33$ & $-1,41$ & \\
\hline Total & 100,15 & 99,34 & 99,78 & 99,08 & 97,26 & 99,85 & 87,72 & 98,34 & 88,00 & 97,91 & 100,35 & 56,26 \\
\hline
\end{tabular}

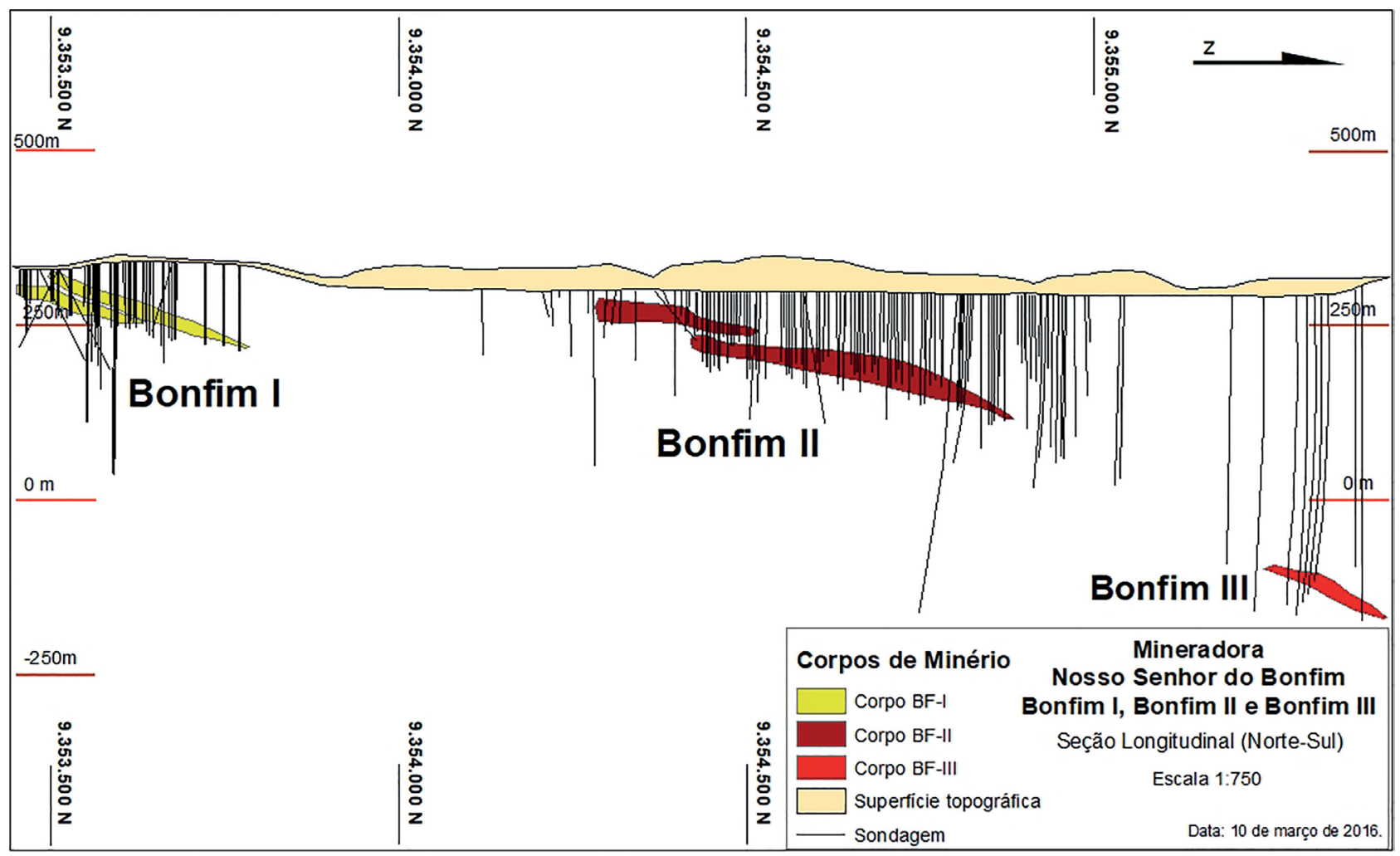

BF: Bonfim

Figura 10. Seção longitudinal (direção N-S) mostrando os depósitos Bonfim-I, Bonfim-II e Bonfim-III ao longo do trend estrutural NNE, que forma o Sistema Estrutural Bonfim. 
Além disso, a circulação das soluções mineralizantes na família de fraturas de cisalhamento de direção WNW-ESE ocorreria em condições de baixo grau metamórfico, sendo corroborado pela presença de prehnita na ganga das fraturas mineralizadas, a qual indicaria a precipitação do ouro associado a bismuto e telúrio em fácies prehnita-pumpellyita, em regime de caráter predominantemente rúptil, o que corresponderia à segunda fase de mineralização, constituindo o sistema Au-Bi-Te.

Considerando as exposições rochosas na superfície da Mina Bonfim-II, notadamente o pegmatito aflorante a oeste, bem como as descrições de sondagem aliadas ao mapeamento geológico-estrutural das galerias da mina, foi elaborada e interpretada a seção geológica W-E. Essa seção corresponde ao perfil de uma seção geológica do depósito Bonfim-II (Figura 11), mostrando o comportamento dos escarnitos boudinados em subsuperfície, juntamente com as camadas de mármores, bem como a continuidade e a estruturação dos litotipos em profundidade na unidade de flogopita xistos granadíferos sulfetados, ricos em pirrotita, até o contato com ortognaisses. Estes constituem o embasamento em Bonfim, conforme intersectado por sondagem em um dos furos mais profundos da Mina Bonfim, o SEB-291, com 285,35 $\mathrm{m}$ de profundidade.

Xenólitos do xisto da Formação Seridó são encontrados dentro do pegmatito presente na parte oeste do perfil geológico W-E (Figura 11), comprovando com relações de campo que os pegmatitos são mais jovens do que os xistos Seridó, ou seja, que fazem parte de evento magmático ocorrido no fim do Brasiliano.

Observa-se ainda, no perfil geológico, que, além dos escarnitos presentes na mina, podem haver outros corpos

W

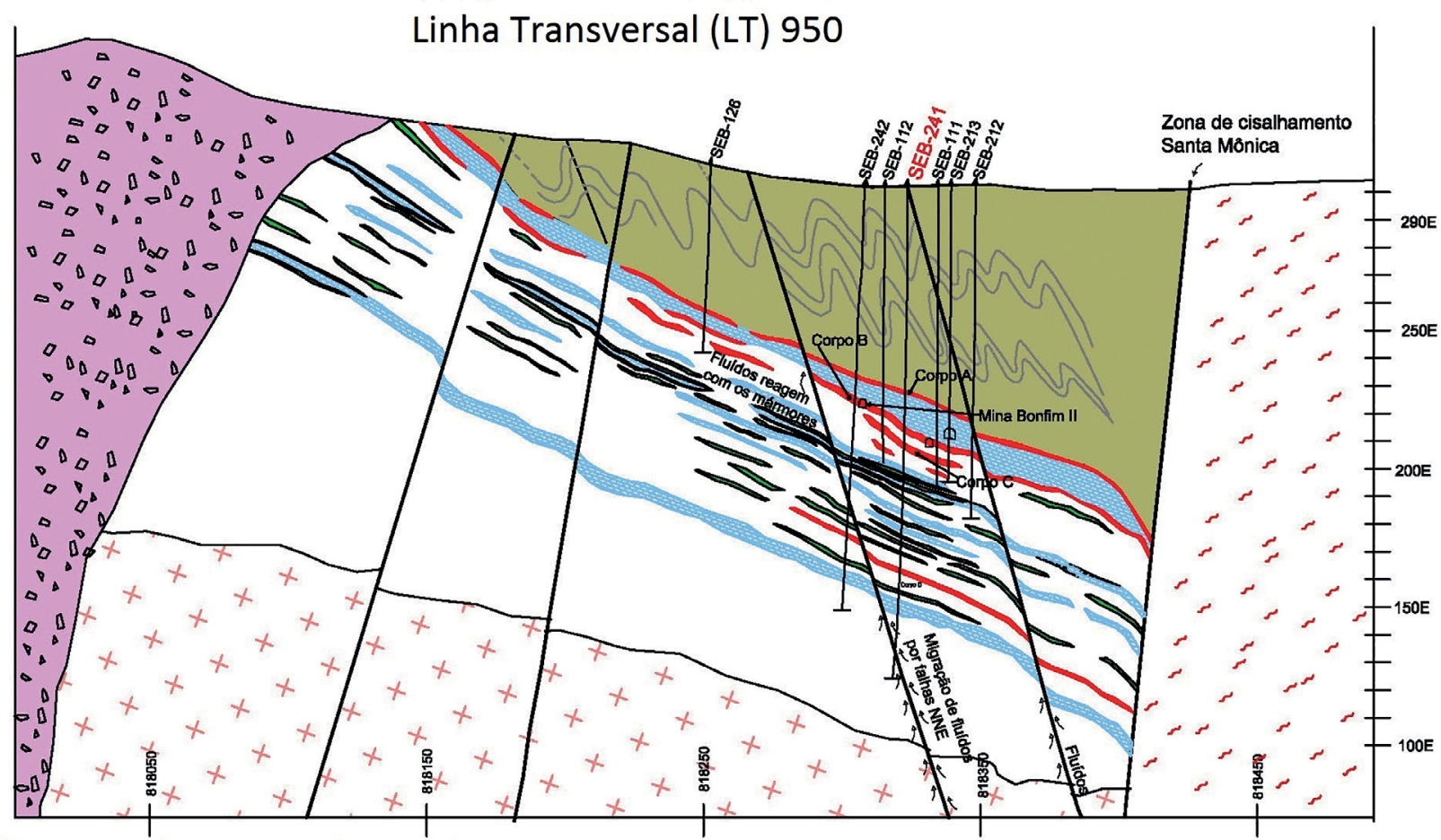

F.0. Pegmatito (magmatismo brasiliano) Quartzo biotita xistos (xisto Seridó) Escarnitos

Mármores (bandados)

Granada flogopita xisto e mármores

Ortognaisses (Complexo Caicó)

Granito gnaisse (embasamento)

SEB: Sistema Estrutural Bonfim.

Figura 11. Seção geológica interpretada com base em sondagem e mapeamento de galerias da Mina Bonfim-Il e também afloramentos em superfície. Perfil mostrando o comportamento dos escarnitos em profundidade e a possível influência do pegmatito na mineralização. 
tanto em profundidade quanto lateralmente (por exemplo, a Mina Oiticica a leste de Bonfim), o que deve ser utilizado como um guia para prospecção mineral na região. Além disso, intrusões pegmatíticas forneceriam os fluidos hidrotermais responsáveis pela mineralização aurífera.

Trabalhos anteriores sobre a geologia e o controle estrutural do minério em Bonfim consideravam que o escarnito estivesse dobrado, e que o controle estrutural da mineralização correspondia ao eixo de dobras com baixo ângulo de caimento, segundo a direção NNE (Salim, 1979). Trabalhos mais recentes ainda continuam atribuindo o corpo de minério de Bonfim ao dobramento isoclinal gerado por cisalhamento, mas situam o granito Bonfim, a oeste da mina e aflorante na serra, no núcleo de um grande antiforme (Souza Neto et al., 2008).

O escarnito que constitui o minério de Bonfim é um corpo bandado de direção NNE-SSW com mergulho para SE. Contudo, se fosse uma dobra, conforme citado na bibliografia, ele deveria ocorrer no outro flanco, com mergulho para NW, o que não é observado. Desse modo, com base nas evidências do acompanhamento nas galerias subterrâneas e considerando o mapeamento estrutural da mina, observou-se que o corpo de minério corresponde a um corpo boudinado por cisalhamento.

$\mathrm{O}$ arcabouço tectonoestrutural no nordeste da Província Borborema é marcado por extensas zonas de cisalhamento de direção NNE-SSW, que também correspondem a zonas de contato entre unidades litológicas. Na região de Bonfim-II, o contato tectônico entre os ortognaisses do Complexo Caicó e sequência metassedimentar do Grupo Seridó é marcado pela zona de cisalhamento Santa Mônica (Costa e Dantas, 2014), situada imediatamente a leste da Mina Bonfim-II (Figura 11).

\section{CONSIDERAÇÕES FINAIS}

O corpo de minério da Mina Bonfim-II (Corpo B) é constituído de um escarnito formado por meio de metassomatismo gerado por fluidos carreados em zonas de cisalhamento. Esses fluidos infiltraram-se ao longo do contato entre tremolita-flogopita mármores e flogopita xistos, provocando alteração e substituição da camada de mármore, propiciando a formação do escarnito. Restaram raras porções reliquiares de mármore dolomítico preservado sob a forma de boudins no interior do escarnito estratiforme.

$\mathrm{O}$ escarnito foi submetido à deformação em zona de cisalhamento, sendo afetado por processo de boudinagem. O corpo de minério encontra-se cisalhado e estirado com caimento suave $\left(12^{\circ}\right)$ ao longo da direção $\mathrm{N} 10^{\circ} \mathrm{E}$, que corresponde ao plunge estrutural da mineralização de Bonfim. O processo de formação do escarnito e, consequentemente, sua deformação teriam ocorrido sob condições dúcteis em profundidades da crosta da ordem de $10 \mathrm{~km}$, em fácies xisto verde alto a anfibolito.

A mineralização de tungstênio (scheelita) e molibdênio (molibdenita) estaria relacionada a esse ambiente profundo, representando a primeira fase de mineralização do sistema (W-Mo), com a formação do escarnito passando por estágios de metassomatismo progressivo e regressivo. Posteriormente, a tectônica teria soerguido a mineralização a níveis crustais mais rasos $(<5 \mathrm{~km})$, favorecendo a mobilização e a deposição de ouro em falhas e fraturas de cisalhamento subverticais de direção NW à WNW, em regime dúctil-rúptil na fácies metamórfica prehnita-pumpelliyta. Essas condições estariam relacionadas a um ambiente epitermal, caracterizando a segunda fase de mineralização no sistema Au-Bi-Te.

Os minerais metálicos identificados por minerografia e análises de microssonda eletrônica foram ouro nativo, bismuto nativo, bismutinita, joseíta, molibdenita, pirrotita e calcopirita, além de hedleyita e gersdorffita, estes descritos pela primeira vez no depósito Bonfim, correspondendo a uma contribuição à assembleia de minerais opacos. Os silicatos, por sua vez, provavelmente incluem uma granada cromífera tipo uvarovita.

A mineralização aurífera está intimamente associada a bismuto e telúrio, em falhas e fraturas de cisalhamento sintéticas com terminação em splay. Essas fraturas seccionam o bandamento principal do escarnito disposto segundo a direção NNE-SSW, sendo, desse modo, estruturas tardias. A presença de prehnita na composição da ganga das estruturas mineralizadas em ouro mostra que o filossilicato pode ser interpretado como um indicador das condições metamórficas de fácies prehnita-pumpelliyta para a segunda fase de mineralização do escarnito.

As fraturas mineralizadas em ouro, compostas de minerais metálicos de bismuto de cor escura, normalmente correspondem a estruturas verticalizadas e espaçadas entre si, podendo expressar, ainda, uma conotação de veios estreitos mineralizados, sob a forma de sheeted veins.

Portanto, sugere-se que a formação do escarnito (primeira fase) teria ocorrido durante o pico do metamorfismo em $577 \pm 5 \mathrm{Ma}$ (Hollanda et al., 2017). Há datações para leucogranitos variando entre essa idade e $526 \pm 8 \mathrm{Ma}$, e ainda idade Re/Os em molibdenita de Bonfim, mensurada em $524 \pm 2 \mathrm{Ma}$, segundo datações feitas por Hollanda et al. (2017). A evolução dos estágios progressivo e regressivo de metassomatismo levou, no final, a constituir a mineralização W-Mo sob regime de deformação dúctil em fácies xisto verde a anfibolito. Por outro lado, a mineralização aurífera seria mais jovem, com idade em torno de $524 \mathrm{Ma}$ (Hollanda et al., 2017). Tal fato nos leva ainda a propor que o pegmatito Bonfim, relacionado à fase final do Brasiliano, seja a fonte de fluidos e calor para impulsionar a mineralização aurífera. Essa proposição pode ser corroborada, uma vez 
que, na mina, existem falhas e fraturas mineralizadas em ouro e bismuto que também possuem feldspato potássico.

O potencial para exploração mineral em Bonfim é alto, no entanto necessita de investimento em sondagem profunda, tanto ao longo do trend estrutural NNE no Sistema Bonfim - sabendo-se que Bonfim-III encontra-se a $400 \mathrm{~m}$ de profundidade e possui poucos furos de sonda - quanto no trend estrutural para SSW, onde existem anomalias geoquímicas de $\mathrm{Au}$ e $\mathrm{WO}_{3}$ aliadas à presença de afloramentos de escarnitos e mármores. Estes também devem ser investigados com sondagem para melhor definição do potencial.

\section{REFERÊNCIAS}

Almeida, F. F. M., Hasui, Y., Brito Neves, B. B., Fuck, R. A. (1977). Províncias estruturais brasileiras. VIII Simpósio de Geologia do Nordeste, 363-391. Campina Grande: SBG/ Núcleo Nordeste.

Almeida, F. F. M., Hasui, Y., Brito Neves, B. B., Fuck, R. A. (1981). Brazilian structural provinces: an introduction. Earth Science Reviews, 17(1-2), 1-29. https://doi. org/10.1016/0012-8252(81)90003-9

Angelim, L. A. A., Torres, H. H. F., Santos, C. A., Veiga Junior, J. P., Medeiros, V. C., Nesi, J. R., Mendes, V. A. (2006). Geologia e Recursos Minerais do Estado do Rio Grande do Norte. Mapeamento Geológico. Escala 1:500.000. Rio Grande do Norte: Companhia de Pesquisa e Recursos Minerais/CPRM, Ministério das Minas e Energia. Programa Geologia do Brasil, 105p.

Anthony, J. W., Bideaux, R. A., Bladh, K. W., Nichols, M. C. (1990). Handbook of Mineralogy, Elements, Sulfides, Sulfosalts. Tucson: Mineral Data Publishing. v. 1. 588 p.

Archanjo, C. J., Viegas, L. G. F., Hollanda, M. H. B. M., Souza, L. C., Liu, D. (2013). Timing of the HT/LP transpression in the Neoproterozoic Seridó Belt (Borborema Province, Brazil): constraints from U-Pb (SHRIMP) geochronology and implications for the connections between NE Brazil and West Africa. Gondwana Research, 23(2), 701-704. https:// doi.org/10.1016/j.gr.2012.05.005

Baumgartner, R., Romer, R. L., Moritz, R., Sallet, R., Chiaradia, M. (2006). Columbite-Tantalite-bearing granitic pegmatites from the Seridó Belt, NE Brazil: Genetic constraints from $\mathrm{U}-\mathrm{Pb}$ dating and $\mathrm{Pb}$ isotopes. Canadian Mineralogist, 44(1), 69-86. https://doi.org/10.2113/gscanmin.44.1.69

Carvalho, O. O. (1990). Geologia e petroquímica de uma sequência metavulcanossedimentar do nordeste da Faixa
Seridó/Sudeste de Lajes, Rio Grande do Norte. Dissertação (Mestrado). Brasília: Instituto de Geociências - Universidade de Brasília.

Companhia de Pesquisa e Recursos Minerais (CPRM). (1971). Projeto Bonfim. Relatório Final. Recife: CPRM. 38 p.

Costa, A. P., Dantas, A. R. (2014). Carta Geológica e de Recursos Minerais, Folha SB.24-X-D-VI, Lajes - Rio Grande do Norte. Programa Geologia do Brasil. Escala 1.100.000. Recife: Companhia de Pesquisa e Recursos Minerais.

Costa, A. P., Dantas, A. R. (2018). Geologia e Recursos Minerais da Folha Lajes SB.24-X-D-VI. Estado do Rio Grande do Norte. Programa Geologia do Brasil. Escala 1.100.000. Recife: Companhia de Pesquisa e Recursos Minerais. 163 p.

Dantas, E. L., Van Schmus, W. R., Hackspacher, P. C., Fetter, A. H., Brito Neves, B. B., Cordani, U., Nutman, A. P., Williams, I. S. (2004). The 3.4-3.5 Ga São José do campestre massif, NE Brazil: remnants of the oldest crust in South America. Precambrian Research, 130(1-4), 113-137. https://doi.org/10.1016/j.precamres.2003.11.002

Docegeo. (1996). Avaliação do Potencial Aurífero do Prospecto Bonfim. Relatório Interno, Distrito Leste. Salvador, Brasil.

Fossen, H. (2010). Structural Geology. Cambridge: Cambridge University Press. 272 p.

Gama Jr., T., Albuquerque, C. A. R. (1985). Petrologia do Grupo Seridó, Currais Novos-Parelhas (RN). Revista Brasileira de Geociências, 15(2), 131-138.

Hackspacher, P. C., Sá, J. M. (1984). Critério lito-estrutural para diferenciação do embasamento Caicó do Grupo Seridó, RN-Brasil. XXI Simpósio de Geologia do Nordeste, v. 9, 263-277. Natal: SBG-Núcleo Nordeste. 473 p.

Hollanda, M. H. B. M., Archanjo, C. J., Souza, L. C., Dunyi, L., Armstrong, R. (2011). Long-lived Paleoproterozoic granitic magmatism in the Seridó-Jaguaribe domain, Borborema Province - NE Brazil. Journal of South American Earth Sciences, 32(4), 287-300. https://doi.org/10.1016/j. jsames.2011.02.008

Hollanda, M. H. B. M., Souza Neto, J. A., Archanjo, C. J., Stein, H., Maia, A. C. S. (2017). Age of the granitic magmatism and the W-Mo mineralizations in skarns of the Serido belt (NE Brazil) based on zircon U-Pb (SHRIMP) and Re-Os determinations. Journal of South American Earth Sciences, 79, 1-11. https://doi.org/10.1016/j.jsames.2017.07.011 
Jardim de Sá, E. F. (1984). Geologia da região do Seridó: reavaliação dos dados. XI Simpósio de Geologia do Nordeste. Boletim do Núcleo Nordeste, n. 9, p. 278-296. Natal: SBG-Núcleo Nordeste.

Jardim de Sá, E. F. (1994). A Faixa Seridó (Província Borborema, NE do Brasil) e o seu significado geodinâmico na cadeia Brasiliana/Pan Africana. Tese (Doutorado). Brasília: Instituto de Geociências, Universidade de Brasília, 803 p.

Jardim de Sá, E. F., Macedo, M. H. E., Legrand, J. M., McReath, I., Galindo, A. C. (1987). Proterozoic granitoids in a polycyclic setting: the Serido region, NE Brazil. International Symposium on Granites and Associated Mineralizations, v. 1, p. 102-110. Salvador: Superintendência de Geologia e Recursos Minerais.

Jardim de Sá, E. F., Salim, J. (1980). Reavaliação dos conceitos estratigráficos na Região do Seridó (RN-PB). Mineração e Metalurgia, 417, 16-28.

Legrand, J. M., Liegeois, J. P., Deutsch, S. (1991). Datação $\mathrm{U} / \mathrm{Pb}$ e $\mathrm{Rb} / \mathrm{Sr}$ das rochas pré-cambrianas da região de Caicó. Reavaliação da definição de um embasamento arqueano. XIV Simpósio de Geologia do Nordeste, 12, 276-279. Recife: SGB.

Leterrier, J., Jardim de Sá, E. F., Bertrand, J. M., Pin, C. (1994). Ages U-Pb sur zircon de granitoides "brasilianos" de la ceinture du Seridó (Province Borborema, NE Brésil). Paris: Académie des Sciences. Série II. v. 318.

Lima, E. A. M. (ed.). (1980). Projeto Scheelita Seridó. Relatório final e mapas. v. 1-35. Recife: Departamento Nacional de Produção Mineral/DNPM e Companhia de Pesquisa e Recursos Minerais. Disponível em: $<$ http:// rigeo.cprm.gov.br/jspui/handle/doc/9240>. Acesso em: 20 maio 2018.

Lima, E. S. (1986). Metamorphism and tectonic evolution in the Seridó region, northeastern Brazil. Tese (PhD). Los Angeles: University of California.

Medeiros, V. C., Nascimento, M. A. L., Galindo, A. C., Dantas, E. L. (2012). Augen gnaisses riacianos do Domínio
Rio Piranhas-Seridó, Província Borborema, Nordeste do Brasil. Geologia USP. Série Cientifica, 12(2), 3-14. https:// doi.org/10.5327/Z1519-874X2012000200001

Nascimento, M. A. L., Galindo, A. C., Medeiros, V. C. (2015). Ediacaran to Cambrian magmatic suites in the Rio Grande do Norte domain, extreme Northeastern Borborema Province (NE of Brazil): Current Knowledge. Journal of South American Earth Science, 58, 281-299. https://doi. org/10.1016/j.jsames.2014.09.008

Salim, J. (1979). Geologia e controles das mineralizações scheelitiferas da região da Serra do Feiticeiro e Bonfim/ Lajes, Rio Grande do Norte-Brasil. Dissertação (Mestrado). Brasília: Instituto de Geociências, Universidade de Brasília.

Souza, L. C., Martins Sá, J., Legrand, J. M., Maia, H. N., Melo, T. F., Magalhães, W. G., Cocentino, W. M., Menezes, C. P., Fillippi, R. (2017). Geologia e Recursos minerais da Folha Pau dos Ferros SB.24-Z-A-II. Escala 1:100.000. Estado do Rio Grande do Norte. Recife: CPRM - Serviço Geológico do Brasil/UFRN. Disponível em: <http://rigeo.cprm.gov. br/jspui/handle/doc/17717> . Acesso em: 21 maio 2018.

Souza Neto, J. A., Legrand, J. M., Volfinger, M., Pascal, M. L. (1998). Geochemistry of the ore fluids in the Bonfim and Itajubatiba gold skarn deposits, Northeastern Brazil: a PIXE Method study. Mineralogical Magazine, 62A(3), 1432-1433. https://doi.org/10.1180/minmag.1998.62A.3.84

Souza Neto, J. A., Legrand, J. M., Volfinger, M., Pascal, M. L., Sonnet, P. (2008). W-Au skarns in the Neo-Proterozoic Seridó Mobile Belt, Borborema Province in northeastern Brazil: an overview with emphasis on the Bonfim deposit. Mineralium Deposita, 43(2), 185-205. https://doi.org/10.1007/ s00126-007-0155-1

Van Schmus, W. R., Brito Neves, B. B., Williams, I. S., Hackspacher, P. C., Fetter, A. H., Dantas, E. L., Babinski, M. (2003). The Seridó Group of NE Brazil, a late neoproterozoic pre- to syn-collisional basin in west Gondwana: insights from SHRIMP U-Pb detrital zircon ages and Sm-Nd crustal residence (TDM) ages. Precambrian Research, 127(4), 287-327. https://doi.org/10.1016/S0301-9268(03)00197-9 